\title{
ARTICLE
}

\section{THE FAILURE OF IMMIGRATION APPEALS}

\section{DAVID HAUSMAN ${ }^{\dagger}$}

Within the same immigration court, some immigration judges are up to three times more likely than their colleagues to order immigrants deported. Theories of appeal and of administrative adjudication imply that appeals processes should increase consistency. This Article uses an internal administrative database, obtained by Freedom of Information Act request, to demonstrate that the appeals process for the immigration courts - a system of administrative adjudication that makes as many decisions as the federal courts-does not promote uniformity. The removal orders of harsher immigration judges are no more likely to be reversed on appeal by the Board of Immigration Appeals or federal courts of appeals.

Why? I find that the Board of Immigration Appeals and the courts of appeals fail to promote uniformity across immigration judges because they review an unrepresentative sample of cases. Harsher immigration judges more often order immigrants deported early in their proceedings, before they have found a lawyer or filed an application for relief. Immigrants without lawyers rarely appeal. The Board therefore rarely reviews the removal orders of immigrants who might have meritorious claims but who are assigned harsh judges and lack lawyers at the beginning of their proceedings.

These quantitative findings, together with interviews and immigration court observation, lead to three incremental, practical policy recommendations. First, the Board of Immigration Appeals and the courts of appeals should adopt a less deferential standard

$\dagger$ Ph.D. Candidate in Political Science, Stanford University; J.D., 2015, Stanford University. I would like to thank Stanford Law School and the Stanford Center on Poverty and Inequality for research funds. Many thanks to Farrin Anello, Graeme Blair, Ingrid Eagly, David Engstrom, Justin Grimmer, Daniel Ho, Christopher Hu, Herbert Kritzer, Ken Mayeaux, Bernadette Meyler, Terry Moe, Andrew Powell, Judy Rabinovitz, Jaya Ramji-Nogales, Cristina Rodríguez, Steven Shafer, Justin Simard, Jayashri Srikantiah, Michael Tan, Christopher Walker, Cecillia Wang, Judge Stephen F. Williams, David Zaring, and Emily Zhang for help, comments, and criticism. Special thanks to the Executive Office for Immigration Review FOIA Service Center for its help in obtaining the data. Finally, thanks to Markus Brazill, Jacob Singer, Kaiyi Xie, and the rest of the editors of the University of Pennsylvania Law Review for their extraordinary help and care in the editing process. 
of review of an immigration judge's denial of a request for a continuance to seek representation. Second, the government should take simple steps to make applications for relief easier to fill out. Third, the Board of Immigration Appeals should hear a random sample of cases in addition to those appealed by the litigants. More broadly, these findings offer further reason-in addition to basic access-to-justice concerns-to support calls for the government to appoint counsel for immigrants in removal proceedings.

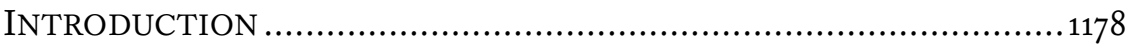

I. UNIFORMITY AND THEORIES OF ADMINISTRATIVE APPEAL ..... 1181

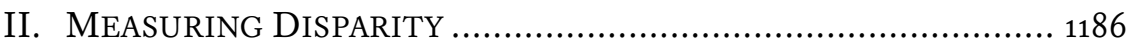

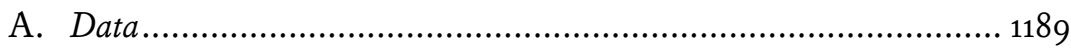

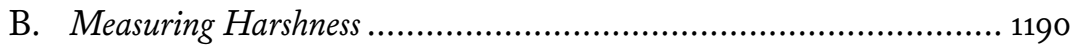

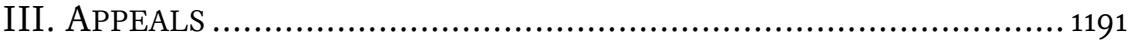

A. The Board of Immigration Appeals .............................................. 1192

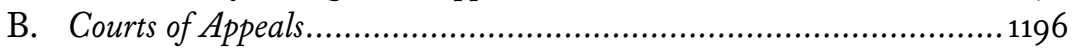

IV. Time, LaWYERS, AND SELECTION BIAS IN APPEALS ..................1197

A. Time, Encouragement, and Access to Counsel and Relief .................. 1198

1. Providing Time to Access Counsel ................................... 1198

2. Influencing Immigrants' Litigation Strategy ...................... 1201

B. Selection Effects on Appeal ....................................................... 1203

C. 2002 Streamlining at the Board of Immigration Appeals .................. 1205

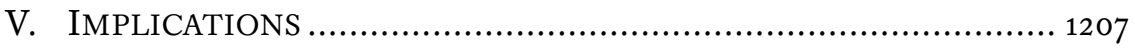

A. Immigration Adjudications .....................................................1208

1. Review of Denials of Continuances ...................................1208

2. Practical Changes to Application for Relief Process ............1209

3. Review of Additional Cases................................................ 1211

4. Adoption of Government-Provided Counsel

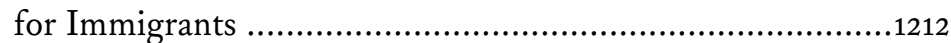

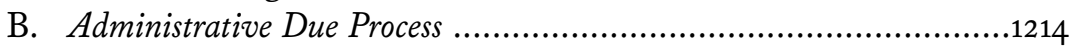

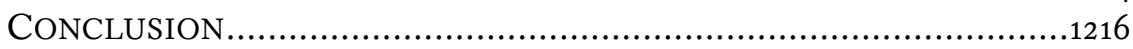

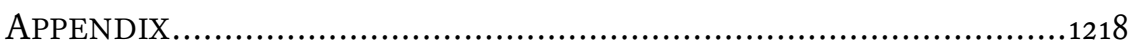

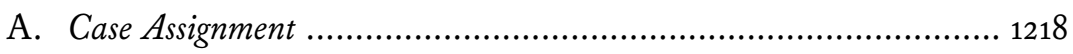

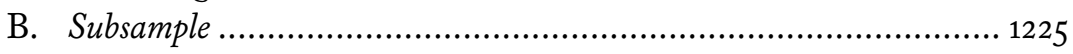

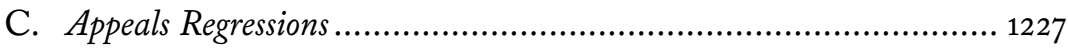

\section{INTRODUCTION}

In some immigration courts, the arbitrary assignment of a judge can increase or decrease an immigrant's chance of being deported by up to forty percentage points. These disparities are large not only in absolute terms, but also relative to other well-known judicial disparities. For example, disparities 
in rates of deportation are three times larger, on average, than disparities in federal judges' decisions about whether to incarcerate criminals. 1

Immigrants 2 who are ordered deported by a particularly harsh judge may appeal that judgment to the Board of Immigration Appeals (BIA), and from there to a federal court of appeals. ${ }^{3}$ One might expect this appeals process to counteract disparities across immigration judges. Does it? If not, why not?

To answer these questions, I use a database, obtained by Freedom of Information Act request, that includes records of every immigration court proceeding initiated over the last two decades. ${ }^{4}$ The database contains information about immigrants' nationalities and lawyers, the location of their immigration proceedings, the immigration charges against them, and the applications for relief that they filed. It also tracks success on appeal. The long timespan covered by the data allows cases to be traced from beginning to end, even when a case lasts over ten years, as some do.

The data reveal that the BIA is, surprisingly, not more likely to reverse the removal orders of relatively harsher judges (immigration judges who deport more immigrants than their court's average). I argue that this pattern (or lack of one) reflects the fact that judges who hesitate to issue removal orders also allow immigrants far more time to find a lawyer. Some judges allow cases to last up to two years longer, on average, than cases before other judges in the same court. Immigrants who appear before these generous judges are therefore more likely to have a lawyer by the time their case is decided. Because immigrants with a lawyer are far more likely to appeal, cases decided by generous judges are thus more often reviewed and reversed.

These findings advance the empirical literature on immigration courts and administrative review. First, the new and comprehensive data set makes it possible to track, for the first time, disparities across judges for all cases across three levels of adjudication-immigration courts, the BIA, and courts of appeals. Second, in measuring cross-judge disparities, I consider and account for the lack of pure random assignment of cases to judges. Third, previous empirical scholarship on immigration courts has focused on the subset of

1 See Crystal S. Yang, Have Inter-Judge Sentencing Disparities Increased in an Advisory Guidelines Regime? Evidence from Booker 32 (Coase-Sandor Inst. for Law \& Econ., Working Paper No. 662, 2014) (finding that the maximum standard deviation of judges' incarceration rates over all periods under study was 2.7 percentage points).

2 For simplicity, I refer to respondents in immigration court as "immigrants," even though some such respondents entered the country on nonimmigrant visas.

3 See 8 U.S.C. $\$ 1252(a)(5)$ (2012) ("[A] petition for review filed with an appropriate court of appeals in accordance with this section shall be the sole and exclusive means for judicial review of an order of removal ...."); Martinez v. Napolitano, 704 F.3d 620, 621-22 (9th Cir. 2012) (holding that under $\S 1252(\mathrm{a})(5)$, after an immigration judge orders removal and the BIA affirms, the exclusive way to challenge removal is to petition the appropriate court of appeals).

4 The data set includes just under five million cases. 
cases in which an immigrant applies for asylum;5 I show that the random assignment of an immigration judge affects not only case outcomes, but also whether an immigrant applies for asylum or other relief in the first place. Finally, this Article uses detailed date information from the administrative data set, together with court observation and interviews, to offer a novel explanation for the immigration appeals process's failure to increase consistency in immigration judge decisions.

More broadly, these findings should influence theoretical scholarship on the effectiveness of administrative and judicial appeals. They highlight the mismatch between the (minimal) inquisitorial procedures available for immigrants without lawyers in immigration court and the adversarial system of immigration appeals, which requires immigrants to initiate a written appeal without guidance from the immigration judge. The result of this mismatch is that immigrants without lawyers almost never appeal. Appellate judges therefore hear an unrepresentative sample of cases and are unable to review immigration judges' decisions effectively. The problem of selection bias in appeals is a general one that matters in other types of adjudications as well: whenever some litigants are more likely than others to appeal cases of similar merit, appellate judges hear an unrepresentative sample of cases. I therefore conclude by calling for further research along similar lines in other areas of administrative adjudications.

In sum, this Article brings data to the question of when appeals courts can promote uniformity across inferior court judges. The immigration appeals system fails to do so because judges not only decide whether to order immigrants deported but also influence whether immigrants choose to appeal.

Part I describes normative theories of appeal and their implication that appeals should promote uniformity across inferior courts' judges. Part II introduces a measure of disparities across immigration judges. Disparities in immigration judges' removal decisions are more than three times larger than disparities in federal judges' decisions about whether to send a convicted criminal to prison.6 Part III shows that the BIA and the federal courts of appeals do little to counteract these disparities: neither the BIA nor the circuit courts are more likely to reverse the decisions of harsher judges when immigrants appeal. By contrast, when the government appeals-which it does more than ten times less frequently than immigrants-the BIA more often reverses the decisions of generous judges than those of harsher judges. Part IV explains these findings by matching disparities in final relief rates with disparities in case length, as well as disparities in the likelihood that an immigrant has a lawyer. Generous judges are more likely to let cases last longer, and the immigrants appearing before them

5 See, e.g., infra note 37 and accompanying text.

6 See supra note 1 and accompanying text. 
are therefore more likely to find lawyers and-crucially-to appeal and win on appeal. Part V, finally, draws out the implications of these findings. The Department of Justice could reduce disparities by facilitating applications for relief, providing lawyers to immigrants, and requiring the BIA to review a random sample of cases sua sponte. The courts of appeals could contribute by altering the standard of review for appeals from denials of continuances. Most broadly, these findings offer another reason to think critically about the implications of selection bias on appeal.

\section{UNIFORMITY AND THEORIES OF ADMINISTRATIVE APPEAL}

Uniformity is both a goal of appeals processes and an indication that they are functioning properly. The two core rationales for the availability of appeals-error correction and lawmaking7-require appeals courts to increase consistency in legal decisions. Normative models of administrative justice carry the same implication for intermediate agency review and, more weakly, for judicial review of administrative adjudications. Together, these theories suggest that appeals processes should make the decisions of inferior court judges more uniform. The failure of immigration appeals to do so is troubling.

Why make appeals available at all? First, an appeals court may detect errors made by a trial court. Steven Shavell famously argued that an appeals process may improve error detection by using litigants' knowledge about the accuracy of a judicial proceeding: when litigants believe that the outcome of a proceeding is wrong, they are more likely to expend the cost of appeal, since they think they will win. 8 An error here means anything that would lead to the reversal of the original decision, including a decision not in line with appeals courts' policy preferences. Lewis Kornhauser, for example, built an influential theory of the benefits of judicial hierarchy on the notion that appeals may help a court system reach correct outcomes, where correctness is explicitly defined as uniformity. ${ }^{9}$ Others have described uniformity as a normatively neutral measure of correctness and as a central element of the rule of law.10

7 See Chad M. Oldfather, Error Correction, 85 IND. L.J. 49, 49 (2010) ("Most depictions of appellate courts suggest that they serve two core functions: the creation and refinement of law and the correction of error.").

8 See Steven Shavell, The Appeals Process as a Means of Error Correction, 24 J. LEgal STUD. 379, 387 (1995) ("When the appeals process is optimally employed, disappointed litigants who were the victims of error bring appeals, and those who were not do not bring appeals.").

9 See Lewis A. Kornhauser, Adjudication by a Resource-Constrained Team: Hierarchy and Precedent in a Judicial System, 68 S. CAL. L. REV. 1605, 1628 (1995) (positing that no matter how one conceives the appellate system's function, promoting uniformity is either the express purpose or a necessary result).

10 See, e.g., Oldfather, supra note 7, at 60-61 (arguing that "uniformity seemingly invokes . . the idea that like cases should be treated alike, and ... those who are similarly situated ought to be treated similarly" and concluding that appellate courts' role is to ensure consistency across judges within the same jurisdiction); Jeremy Waldron, Lucky in Your Judge, 9 THEORETICAL INQUIRIES L. 
At a minimum, whether an appeals process produces more uniform outcomes is an indicator of whether it successfully corrects errors. In the immigration court system, the lack of greater uniformity after appeals suggests that the BIA and the courts of appeals are not successfully correcting errors.

Of course, appeals courts do not only correct errors; they also make law by precedent. Yet lawmaking, too, should increase uniformity in lower court outcomes: by elaborating rules that lower court judges must follow, appeals courts reduce the discretion of those judges and promote uniformity across their decisions. Scholars have debated both to what degree a hierarchical system that establishes precedent is desirable11 and whether the federal judiciary actually functions in this way. 12 All agree, however, that when appellate courts elaborate on legal rules, they should guide lower courts, at least to some degree, and lead to greater uniformity.13

The BIA performs this lawmaking function within the Executive Office for Immigration Review (EOIR) by publishing select opinions and, in unpublished opinions, by reviewing immigration judges' decisions for their compliance with the BIA's published decisions. If the BIA successfully sets and enforces policy, its review of immigration judges' decisions should reduce inconsistency by bringing the decisions in line with the policy the BIA has set. No matter whether immigration appeals exist to set policy or to correct errors, they should promote uniformity across immigration judges' decisions.

Just as theories of appeal imply that a legal hierarchy should promote uniformity, so too do theories of administrative adjudication imply that agency appeals bodies should make outcomes more uniform. In a seminal article, Jerry Mashaw set out three competing models of administrative justice. ${ }^{14}$ Uniformity in outcomes is an important goal of administrative

185, 192-93 (2007) (noting that uniformity is a central element of the rule of law while acknowledging that inconsistency in application of the law due to luck cannot be eliminated from a court system).

11 Compare Evan H. Caminker, Precedent and Prediction: The Forward-Looking Aspects of Inferior Court Decisionmaking, 73 TEX. L. REV. 1, 16 (1994) ("The lower courts are merely intended to facilitate universal access to the Court's edicts."), and Evan H. Caminker, Why Must Inferior Courts Obey Superior Court Precedents?, 46 STAN. L. REV. 817, 828-55 (1994) (noting that while arguments in favor of using judicial hierarchy to create uniformity across lower courts are almost "universally" accepted, they are based on several different rationales), with Pauline T. Kim, Lower Court Discretion, 82 N.Y.U. L. REV. 383, 442 (2007) (arguing that because legal rules may sometimes be indeterminate and social needs require flexibility in the application of legal rules, lower courts do not always need to be bound by appellate court pronouncements).

12 See Donald R. Songer et al., The Hierarchy of Justice: Testing a Principal-Agent Model of Supreme Court-Circuit Court Interactions, 38 AM. J. POL. SCI. 673, 681-9o (1994) (reviewing a set of circuit court search and seizure cases and determining that the circuit courts often, but not always, follow Supreme Court precedent).

13 See Kim, supra note 11, at 441 (accepting, with reservations, that "economy and uniformity ... are served by obedience to hierarchical precedent").

14 Jerry L. Mashaw, Conflict and Compromise Among Models of Administrative Justice, 1981 DUKE L.J. 181. 
review regardless of which model one accepts. The first model-the one most prominent in constitutional due process doctrine-considers error avoidance the central purpose of administrative adjudications.15 Mashaw calls this model, which ignores the inherent discretion given to adjudicators, the "bureaucratic rationality" model. $16 \mathrm{He}$ contrasts this prominent model with two others: the "professional treatment" and "moral judgment" models.17 The professional treatment model compares adjudicators to social workers or doctors-professionals whose goal is to treat and help the claimant.18 The moral judgment model recognizes that the discretion granted to adjudicators requires them to exercise ethical as well as factual judgment.19

The failure of the BIA to make outcomes more uniform across judges is troubling for all three of these models of administrative justice. The bureaucratic rationality model requires consistent application of rules to facts and hierarchical control of the decisionmaking process;20 large disparities across judges, uncorrected by the BIA, undermine that goal. The professional treatment model suggests an interpersonal decision structure, but consistency of outcomes is no less important; Mashaw contends that a professional treatment model can only be successful in the context of highly unified professional norms and skills.21 Large disparities in outcomes across judges facing similar cases suggest a lack of professional unity. Finally, large disparities that are left uncorrected after review are perhaps most disturbing for the moral judgment model, which is based on "the neutral application of commonly held moral principles." 22 Uniformity in such legal-ethical judgments is a central element of the rule of law.

These theories of appeal and administrative adjudication suggest that immigration appeals should make both legal and factual decisions more uniform. If some immigration judges consistently make errors-either in favor of the government or in favor of immigrants-then appeals to the BIA and courts of appeals should increase consistency across judges on both legal and factual questions.23 If appeals courts make policy, they should similarly bring immigration judges' legal and factual determinations in line with that policy.

$15 \mathrm{Id}$. at 185 .

$16 \mathrm{Id}$.

17 Id. at $186,188$.

$18 \mathrm{Id}$. at 186 .

19 Id. at 188 .

$20 \mathrm{Id}$. at 185 .

21 Id. at $186-87$.

22 Id. at 189; see also id. at 188 ("[T]he goal of a moral-judgment model of justice . . . [is] factually correct applications of previously validated legal norms.”).

23 Immigration judges make three main types of decisions, all of which should be made more uniform by appellate review. First, immigration judges decide whether a respondent is removable. 8 U.S.C. $\S 1229 a(a)(1)$ (2012). This determination usually raises legal questions, such as whether a 
Of course, the deference that the BIA and the courts of appeals owe to immigration judges constrains their ability to promote uniformity. Although normative theories broadly agree that appeals should promote uniformity, the responsibility to promote uniformity is more central for within-agency appeals bodies than for Article III courts. Scholars and judges continue to debate how much deference Article III courts should grant to legal decisions and findings of fact in administrative adjudications.24 I do not enter that debate, but rather accept the broad consensus, among academics and courts, that within-agency appeals bodies should defer less than Article III courts to the decisions of administrative judges. 25

The standards of review applied by the BIA and the federal courts of appeals in immigration cases reflect this distinction. The BIA reviews questions of law de novo and reviews immigration judges' findings of fact for clear error.26 By contrast, courts of appeals must affirm findings of fact that are supported by substantial evidence: "[T]he agency's factual findings are 'conclusive unless any reasonable adjudicator would be compelled to conclude to the contrary." 27 Moreover, the REAL ID Act of $2005^{28}$ stripped the circuit courts of jurisdiction to review denials of several forms of discretionary

particular state crime fits the federal definition of an aggravated felony. See id. $\S 1101(\mathrm{a})(43)$ (including within the definition of "aggravated felony" the state crime equivalents of enumerated federal offenses). Second, immigration judges decide whether respondents are eligible to apply for various forms of relief. $I d$. $\S 1229 \mathrm{a}(\mathrm{c})(4)(\mathrm{A})$. These decisions, too, raise largely legal questions - for example, the commission of an aggravated felony precludes most forms of relief. See, e.g., id. $\S 1229 \mathrm{~b}(\mathrm{a})(3)$ (permitting cancellation of removal for respondents only if they have not been convicted of an aggravated felony). Finally, immigration judges make discretionary factual determinations when deciding whether to grant relief. Id. $\S 1229 \mathrm{a}(\mathrm{b})(1)$. For all of these types of decisions, harsher immigration judges are more likely to err on the side of denying relief and affirming removability, and more generous immigration judges more likely to err in the opposite direction. An appeals system that promotes uniformity should therefore reduce disparities across immigration judges both for decisions related to removability and decisions related to relief.

24 See, e.g., Louis L. Jaffe, Judicial Review: "Substantial Evidence on the Whole Record," 64 HARV. L. REV. 1233, 1261 (1951) (reading cases interpreting the standard of review for findings of fact as properly establishing an area of administrative discretion); Robert Kramer, The Place and Function of Judicial Review in the Administrative Process, 28 FORDHAM L. REV. 1, 11 (1959) (endorsing substantial judicial deference to administrative action, limiting review to "where its merits clearly outweigh its disadvantages"); Cass R. Sunstein, On the Costs and Benefits of Aggressive Judicial Review of Agency Action, 1989 DUKE L.J. 522, 536 (emphasizing the difficulty of assessing the strengths and weaknesses of robust judicial review of agency action).

25 See, e.g., Kramer, supra note 24 , at 78 ("An agency is not an inferior tribunal or a lower court judge, but rather an autonomous body, applying specialized knowledge and experience to regulate areas demanding flexibility and complex judgments. Courts cannot and should not be made to guarantee the correctness of every agency decision.").

268 C.F.R. $\S 1003.1(\mathrm{~d})(3)(\mathrm{i})$-(ii) (2015).

27 Huo Qiang Chen v. Holder, 773 F.3d 396, 403 (2d Cir. 2014) (quoting 8 U.S.C. § 1252(b)(4)(B)).

28 REAL ID Act of 2005, Pub. L. No. 109-13, 119 Stat. 302 (codified in scattered sections of 8 U.S.C.). 
relief 29 as well as findings of fact underlying the removal orders of immigrants convicted of certain crimes. The courts of appeals retain the authority to review legal and constitutional questions, 30 but the legal conclusions of the BIA are often entitled to deference.31 In other words, courts of appeals are more deferential to immigration judges' decisions than is the BIA with respect to both questions of law and questions of fact. One would therefore expect the courts of appeals to play a more limited role than the BIA in promoting uniformity, but to play a role nonetheless-deference has limits.

Despite the importance of uniformity, empirical scholarship has only indirectly investigated whether appeals courts achieve this goal. Scholars have so far focused more on compliance than on uniformity; for instance, a large body of work has found that federal appellate court judges usually (but not always) comply with Supreme Court decisions. ${ }^{32}$ Research on the effects of court of appeals review of district court patent claim construction has generated somewhat more mixed results: district court judges whose claim construction decisions have been appealed more often in the past are no more likely to avoid reversal in subsequent appeals, 33 and, before the establishment of the Federal Circuit, the patent policies of district courts and their circuits appeared to be only loosely connected. 34 More recently, Daniel Ho examined

29 See 8 U.S.C. $\$ 1252(\mathrm{a})(2)(\mathrm{B})$ (precluding judicial review of denials of discretionary relief, including cancellation of removal and voluntary departure); id. §1252(a)(2)(C) (precluding judicial review of the removal orders of immigrants convicted of certain classes of crimes); id. $\S 125^{2}$ (a)(4) (precluding judicial review of Convention Against Torture claims). But see id. §1252(a)(2)(D) (providing that these jurisdiction-stripping provisions do not preclude review of constitutional questions or questions of law on petition for review).

30 See Hamid v. Gonzales, 417 F.3d 642, 647 (7 $7^{\text {th }}$ Cir. 2005) (noting that the REAL ID Act provides for review of constitutional questions and questions of law in some cases where judicial review would be otherwise precluded); David M. McConnell, Judicial Review Under the Immigration and Nationality Act: Habeas Corpus and the Coming of REAL ID (1996-2005), 51 N.Y. L. SCH. L. REV. 75, 108 n.177 (2006-07) (listing cases in which courts of appeals dismissed appeals arising from the BIA for lack of jurisdiction due to the REAL ID Act).

31 See Baraket v. Holder, 632 F.3d 56, 58 (2d Cir. 2011) (noting that the Second Circuit applies Chevron deference to the BIA's interpretation of the Immigration and Nationality Act in published, precedential opinions); $c f$. Esparza-Rodriguez v. Holder, 699 F.3d 821, 823-24 (5th Cir. 2012) ("We give Chevron deference to the BIA's interpretation of the term 'moral turpitude' and its guidance on the general categories of offenses which constitute [crimes involving moral turpitude], but we review de novo the BIA's determination of whether a particular state or federal crime qualifies as a [crime involving moral turpitude].”).

32 See, e.g., Sara C. Benesh \& Malia Reddick, Overruled: An Event History Analysis of Lower Court Reaction to Supreme Court Alteration of Precedent, 64 J. POL. 534, 536 (2002) ("[L]ittle evidence of outright defiance has been found in the Court of Appeals."); Donald R. Songer et al., supra note 12, at 681-90 (finding that although circuit judges sometimes indulge their own preferences, they respond strongly to Supreme Court changes in search and seizure policy).

33 David L. Schwartz, Practice Makes Perfect? An Empirical Study of Claim Construction Reversal Rates in Patent Cases, 107 MiCH. L. REV. 223, 225-26 (2008).

34 See Lawrence Baum, Responses of Federal District Judges to Court of Appeals Policies: An Exploration, 33 W. POL. Q. 217, 223 (1980) (concluding that while patent validity decisions were 
consistency in restaurant food safety scoring over time. $35 \mathrm{He}$ compared restaurant inspection and reinspection scores in New York City before and after appeals hearings and found little evidence that appeals hearings increased consistency. 36

Finally, an important new book examines the role of the BIA in asylum decisions and makes important contributions to our understanding of the role of the BIA's ideology. 37 Because it limits its sample to asylum decisions, however, the book does not address the problem that this Article reveals: the BIA cannot effectively review immigration judges' decisions because immigration judges influence whether immigrants find a lawyer and apply for asylum or other forms of relief-and whether they eventually appeal.

The shortage of empirical scholarship on these issues reflects the complexity of the problem. Uniformity is difficult to measure and there are few large sources of data matching adjudications across levels of review. This Article addresses these difficulties with a measure of one aspect of uniformity-cross-judge disparity-and a new database that matches all immigration court outcomes to appeals. The results are troubling. Immigrants whose cases were decided by harsher judges are no more likely to appeal and win than immigrants whose cases were heard by more generous judges.

\section{MEASURING DISPARITY}

Immigration judges vary dramatically in their relief rates-the rates at which they allow immigrants to remain in the United States. To calculate these relief rates, I include not only formal grants of relief-such as grants of applications for asylum or cancellation of removal-but also other outcomes that allow immigrants to remain in the country. 38 An important recent article

significantly related between district courts and their courts of appeals, there was a "substantial gap" between the courts in their "decisional tendencies").

35 Daniel E. Ho, Fudging the Nudge: Information Disclosure and Restaurant Grading, 122 YALE L.J. 574 (2012). For qualitative work on the role of the Social Security Appeals Council, a different administrative review body, see generally JERRY MASHAW ET AL., SOCIAL SECURITY HEARINGS AND APPEALS: A STUDY OF THE SOCIAL SECURITY ADMINISTRATION HEARING SYSTEM (1978); Charles H. Koch, Jr. \& David A. Koplow, The Fourth Bite at the Apple: A Study of the Operation and Utility of the Social Security Administration's Appeals Council, 17 FLA. ST. U. L. REV. 199, 307-08 (1990) (recommending, among other things, that the Appeals Council focus more on policymaking and slow its review of administrative law judges' decisions, allowing it more time to correct errors).

36 Ho, supra note 35 , at 667-70.

37 See BANKS Miller et Al., ImMigration Judges AND U.S. ASYlum POlicy 106-49 (2015) (testing hypotheses about the BIA's role in error correction and policy formulation using a sample of only asylum cases).

38 The most important of these other outcomes is the termination of a case. Termination occurs when the immigration judge concludes that the government did not show by clear and convincing evidence that the immigrant is in the country illegally (i.e., that the immigrant is inadmissible or deportable). See 8 U.S.C. $\S 1182$ (2012) (listing grounds of inadmissibility); id. §1227 (listing 
and book quantified and began to explain disparities in asylum grant rates. 39 This Article builds on that work by showing that immigration judges not only grant relief at different rates, but also affect immigrants' decisions about whether to apply for relief (such as asylum) in the first place and influence immigrants' decisions about whether to appeal. These disparities in case management prevent the BIA from reviewing a representative sample of cases, hobbling the appeals process and preventing it from promoting uniformity.

Disparities across immigration judges are large and highly statistically significant: the average standard deviation of judge relief rates within the nineteen largest courts between 1998 and 2004 was approximately nine percentage points. 40 This means that for an average court, approximately one third of immigrants have their cases decided by judges either nine percentage points harsher or nine percentage points more generous than the court average.

As shown in Figure 1 below, these disparities are many times larger than disparities that would arise purely by chance and are more than three times larger than disparities across federal judges in decisions about whether to send a criminal defendant to prison.

Figure 1 shows three distributions: the actual distribution of immigration judge relief rates; the actual distribution of federal judge decisions about whether or not to send a defendant to prison; ${ }^{41}$ and a simulated distribution of immigration judge decisions in which all judges share the same relief rate and the only deviations from the mean are caused by chance.42 Immigration court disparities are large in both absolute and relative terms.

grounds of deportability). In these cases, the immigrant need not be granted relief to remain in the country; instead, the government's case that she is here illegally is simply terminated.

39 See generally JAYA RAMJI-NOgALES ET AL., REFUgEe ROUlETte: DisPaRities IN ASYLUM ADJUDICATION AND PROPOSALS FOR REFORM (2009) [hereinafter RAMJI-NOGALES ET AL. (2009)]; Jaya Ramji-Nogales et al., Refugee Roulette: Disparities in Asylum Adjudication, 6o STAN. L. REV. 295 (2007) [hereinafter Ramji-Nogales et al. (2007)].

40 See infra Figure 1.

41 To make this distribution visually comparable, I used the standard deviation calculated by Yang, supra note 1, at 32, and simulated a normal distribution with that standard deviation and a mean of zero. Yang suggests that federal judge rates are approximately normally distributed.

42 For each judge, I simulated a relief rate from a binomial distribution based on her court's mean and the actual number of cases she heard during the study period. 
Figure 1: Immigration Court Disparities Compared43

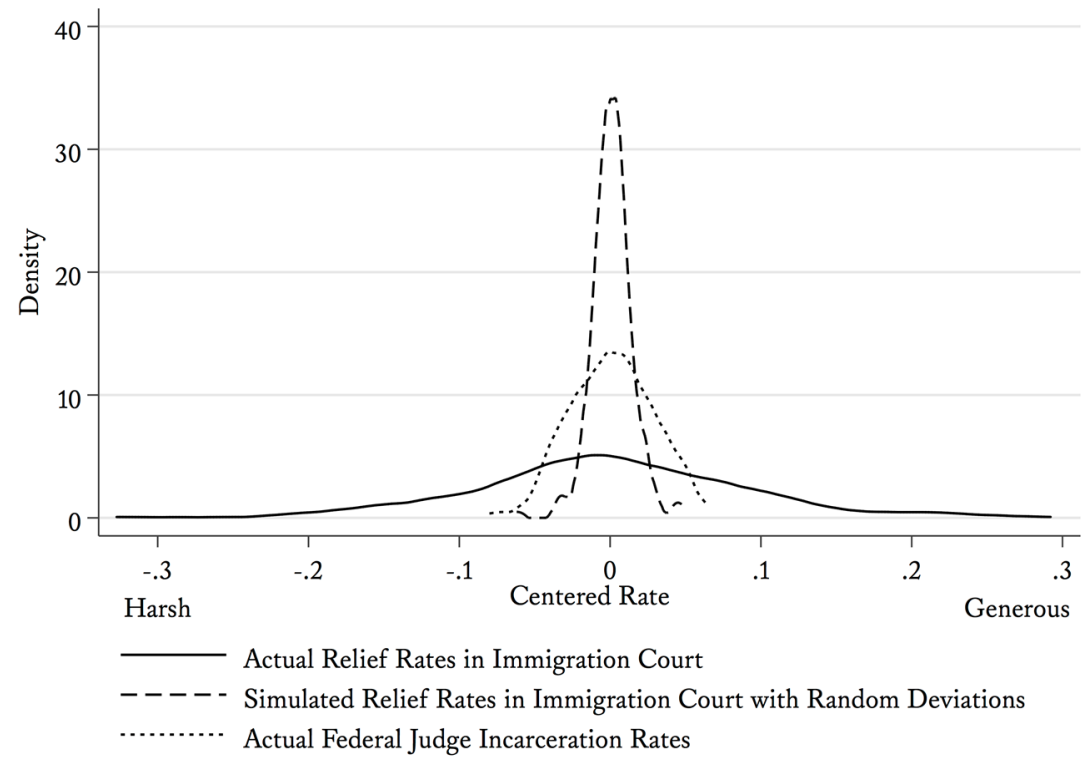

Do these disparities reflect real differences across judges? Perhaps judges decide similar cases similarly but have different relief rates because they hear different types of cases. To address this objection, previous work on disparities in immigration court has relied on the immigration courts' own assertion that cases are randomly assigned to judges.44 In the Appendix, I show that cases are not in fact randomly assigned-likely because cases arrive on dockets in clusters-but that assignment appears arbitrary nonetheless: the merits of the cases do not appear to vary systematically from judge to judge. To be confident that this is accurate, in the Appendix, I replicate these

43 Estimates of immigration judge relief rates include fixed effects and several controls to adjust for differences across immigration courts and caseloads.

44 See U.S. GOV'T ACCOUNTABILITY OFFICE, GAO-06-771, EXECUTIVE OFFICE FOR IMMIGRATION REVIEW: CASELOAD PERFORMANCE REPORTING NEEDS IMPROVEMENT 17 (2006), http://www.gao.gov/assets/260/251155.pdf [https://perma.cc/U8RJ-M2FY] ("Within each immigration court, newly filed cases are generally assigned to immigration judges through an automated process; however, some flexibility exists."). The Report goes on to explain that the random assignment of immigration judges may be modified "to correct inequities that occurred in the number and type of cases that were assigned to a judge by the automated system," as well as to ensure that the same immigration judge hears an immigrant's case if the immigrant previously had a case before that judge. $I d$. Finally, an immigration judge may not be assigned to a case if she already has a heavy caseload. Id. 
measures of cross-judge disparities for a subset of time periods and courts in which assignment appears to have been random. 45

\section{A. Data}

The conclusions of this Article hold for the full database of all nondetained immigration proceedings over the last two decades. For the results presented in the body of the Article, however, I have restricted the sample to exclude cases decided during periods of legal change and cases that were not yet resolved in 2014.

Data come from a Freedom of Information Act request to the EOIR that was honored in March 2014. The database contains records of all immigration court adjudications that were initiated between the early 1990 as and February 28 , 2014. I concentrate on nondetained cases only-the cases in which immigrants were never taken into custody at any point in their proceedings. I exclude detained cases because they are scheduled separately and present different issues. ${ }^{46}$ For example, a continuance in a nondetained case simply gives the immigrant more time; in a detained case, a continuance lengthens the immigrant's detention, which could encourage her to agree to deportation.

To construct the sample, I began by narrowing the database to cases in which the Notice to Appear was issued between January 1, 1998, and August 31, 2004. This was a conservative decision made for two reasons. First, some cases take up to ten years to resolve. I therefore chose a subset of cases for which all appeals had been exhausted for the overwhelming majority of cases. Second, immigration law changed significantly with the passage of the Illegal Immigration Reform and Immigrant Responsibility Act of 1996,47 which affected cases initiated after April 1, 1997.48 I avoided the period of change after its passage by excluding cases in which the Order to Show Cause was issued before 1998.

45 See infra Appendix, Section A.

46 The two types of cases are scheduled separately and, in many courts, different judges are assigned to the nondetained and detained calendars. The detained calendar also implicates two doctrinally separate but practically connected processes: bond and merits determinations. When an immigration judge grants bond, an immigrant's chances of prevailing on her merits claims may increase. For suggestive observational evidence along these lines, see Ingrid V. Eagly \& Steven Shafer, A National Study of Access to Counsel in Immigration Court, 164 U. PA. L. REV. 1, 50 fig.14 (2015) (reporting that from 2007 to 2012, immigrants who were never detained or were released from detention were drastically more successful in their cases than immigrants who were detained). Empirically, this makes it difficult to identify a judge's relief rate, since that rate may depend on the judge's doctrinally separate bond determination. Moreover, granting bond often sends the case to the nondetained calendar and therefore to a different judge. A high bond grant rate may therefore artificially lower a judge's relief rate by clearing meritorious cases from her docket.

47 Illegal Immigration Reform and Immigrant Responsibility Act of 1996, Pub. L. No. 104-208, 110 Stat. 3009-546.

48 See Jimenez-Angeles v. Ashcroft, 291 F.3d 594, 597 (9th Cir. 2002) ("[I]f an alien's case is commenced after April 1, 1997, it appears to be controlled by the new, permanent provisions of the [Illegal Immigration Reform and Immigrant Responsibility Act] . . . .). 
From among the nondetained cases between 1998 and 2004, I kept only those from the largest nineteen immigration courts. I narrowed the data set further by excluding all cases in which an immigrant faced proceedings before more than one judge; most of these were cases in which an immigrant was initially detained and later released. 49 Next, I removed all cases for which the judge was not identified, as well as cases heard before judges who heard fewer than 300 cases in a single immigration court.50 This final step left a data set of 410,875 cases.51 Table 1 below shows the number of cases after each successive sample restriction.

Table 1: Sample Restrictions

\begin{tabular}{lr}
\hline \hline Sample Restriction & $\begin{array}{c}\text { Remaining } \\
\text { Cases }\end{array}$ \\
\hline Total Cases & $4,880,686$ \\
Cases Heard Before One Immigration Judge Only & $4,097,761$ \\
Cases with Consistent Detention Information & $4,094,256$ \\
Nondetained Cases Only & $2,005,761$ \\
Cases Initiated January 1, 1998-August 31, 2005 & 496,087 \\
Cases from 19 Courts with More Than 7000 Cases & 425,652 \\
Cases from Immigration Judges Who Heard at Least & 410,875 \\
300 Cases & \\
\hline
\end{tabular}

\section{B. Measuring Harshness}

To measure how much judges differ in their harshness, I start by calculating judges' relief rates-the percentage of cases in which they allow an immigrant to remain in the United States. I then calculate the standard deviation of those relief rates within courts. When relief rates within the same court vary more, the standard deviation is larger. In order to include control variables and to generate a confidence interval, I use a random effects model, described in detail in Appendix, Section B, infra, that is similar to the model used in Yang's study on sentencing disparities.52 That measure of disparity retains the same interpretation as the simpler one: it is equivalent to the standard deviation of the relief rates within each court, averaged across all

49 Judge change can also occur if the venue changes, if a case has to be calendared urgently and the initial judge's calendar is full, or if a judge leaves a court.

50 These were likely judges visiting from another immigration court or judges who began their terms shortly before the end of the study period.

51 For the full sample of nondetained cases that spanned two decades, I kept all nondetained cases from judges who heard at least 300 cases. The result is a data set with 1,946,239 observations.

52 See Yang, supra note 1. 
nineteen courts, accounting for differences across courts and other control variables. 53 This standard deviation is nine percentage points, meaning that about one third of immigrants had their cases decided by judges whose relief rates were at least nine percentage points below or above the court mean. ${ }^{54} \mathrm{In}$ a court in which $30 \%$ of immigrants obtained relief, this level of disparity meant that the luckiest $15 \%$ of immigrants, assigned to generous judges, were twice as likely to avoid deportation as the unluckiest $15 \%$. One might expect the appeals process to temper this inconsistency; Part III shows that it does not.

\section{APPEALS}

Normative theories of administrative appeal imply that the appeals process should make immigration judges' decisions more uniform, either by correcting errors or by setting precedent in areas of disagreement.55 After the immigration judge makes a final decision ordering an immigrant removed or granting relief,56 the case may proceed through two levels of review. First, either the government or the immigrant may appeal to the BIA.57 Then, if the immigrant loses before the BIA, she may petition for review of the decision by a circuit court of appeals.58 I find that neither level of appellate review substantially increases uniformity across immigration judges' decisions. 59

53 A measure of disparity should be easy to interpret, and it should include a confidence interval. Ramji-Nogales et al., whose important work revealed the extent of disparities in asylum adjudication, suggest two different measures of disparity. Their first measure compares judges' asylum grant rate to the national mean. Ramji-Nogales et al. (2007), supra note 39, at 332-33. As they acknowledge, that measure does not account for cross-court differences in the application pool. Their second measure compares judge relief rates to mean rates within courts: they measure the percentage of judges whose grant rates are $50 \%$ below or above the mean grant rate. Id. at 333-36. This measure usefully takes into account cross-court differences, and it is easy to interpret, but it is sensitive to the level of the court mean. For example, in a court with a mean $20 \%$ grant rate, the $50 \%$ difference would correspond to a ten percentage point difference, but in a different court with a $40 \%$ grant rate, the same $50 \%$ difference would correspond to twice the percentage point difference in the first court. The standard deviation measure lacks this sensitivity, and the random effects model allows me to produce confidence intervals, quantifying the statistical uncertainty in the estimates.

54 The $95 \%$ confidence interval for this standard deviation spans $8.3 \%$ to $10.1 \%$.

55 See supra notes $14^{-22}$ and accompanying text.

568 U.S.C. $\S 1229 \mathrm{a}(\mathrm{c})(1)(\mathrm{A})(2012)$.

578 C.F.R. $\$ 1003 \cdot 38($ a) $(2015)$.

588 U.S.C. $\S 1252(\mathrm{a})(5)$. The Attorney General can also review BIA decisions but does so rarely. See Lindsey R. Vaala, Bias on the Bench: Raising the Bar for U.S. Immigration Judges to Ensure Equality for Asylum Seekers, 49 WM. \& MARY L. REV. 1011, 1016-17 (2007) ("Although the Attorney General possesses the authority to review individual cases after they pass through the Immigration Courts and BIA, the Attorney General rarely exercises that power.").

59 In this Part, as in the rest of the Article, I report results for the 1998-2004 period, but all of the results in this part-the Article's key empirical contributions-also hold for the whole period of the database, from the early 1990 s to 2014. I do not report them here because they may be biased by the exclusion of some recent cases that have not yet been completed. For example, some cases initiated in 2010 may already have led to outcomes, especially if they were heard by harsh judges. If 


\section{A. The Board of Immigration Appeals}

If the BIA counteracts cross-judge disparities and promotes the uniform application of the law, the data on appeals and reversals should display one or both of two patterns. First, the BIA should reverse the relief decisions of generous judges more often than those of harsh judges, and reverse the removal decisions of harsh judges more often than those of generous judges. Alternately, or in addition, litigants may anticipate the BIA's consistencyenhancing effect. In that case, immigrants should appeal the removal orders of harsh judges more often than those of generous judges, and the government should appeal the relief grants of generous judges more often than those of harsh judges. Most importantly, the overall effect of the appeals process - the combined effect of more filings and higher reversal ratesshould be to reduce disparities.

In fact, however, the overall effects of appeals are asymmetric: the BIA is more likely to reverse the decisions of generous judges when the government appeals, but is not more likely to reverse the decisions of harsh judges when immigrants appeal.60 Of course, the BIA may affect outcomes not only by reversing decisions, but also by influencing litigants' decisions as to whether to appeal. A full account of the appeals process therefore requires describing-for both immigrants' and the government's appeals - the filing decisions of the litigants, the outcomes before the BIA, and the combined effect of the two. 61

patterns in cases are changing over time, then excluding cases that take longer may bias the results. The consistency of the patterns for the smaller and larger data sets, however, should increase confidence that these patterns are not spurious.

60 I categorized an immigrant's appeal as successful in obtaining reversal if the BIA's decision is described in the database as "Remand," "Sustain," "Temporary Protected Status," or "Termination." Of course, in a subset of the remanded cases the immigrant may eventually be removed; I ignored that possibility in order to focus on the BIA's behavior. In considering appeals, I included only "case appeals," which account for more than $70 \%$ of all appeals. I excluded motions submitted to the BIA asking it to reopen a case since these motions often reflect changed circumstances rather than an argument that the immigration judge erred. In the relatively uncommon cases in which there was more than one appeal, I considered only the last appeal. In modeling immigrants' decisions to appeal, I included only cases in which the immigration judge, before any appeal, entered an order of removal or voluntary departure. Even though immigrants often waive appeal when they are granted voluntary departure, I included voluntary departure for two reasons. First, some immigrants may appeal the denial of a different form of relief when they are granted voluntary departure. Second, I wanted to capture the behavior of judges who encourage immigrants to accept voluntary departure early in their proceedings and therefore not to appeal. In modeling the government's decision to appeal, I included only immigration judge decisions allowing the immigrant to stay.

$61 \mathrm{I}$ am grateful to Ingrid Eagly and Steven Shafer for pointing out that a majority of nondetained respondents who are ordered removed without lawyers are removed in absentia-that is, without the respondent being present at the hearing. In order to be sure that these in absentia removals are not the source of these patterns on appeal, I have replicated the appeals results excluding all cases in which a respondent was removed in absentia at the first hearing. Excluding these cases actually strengthens the effect of immigration judges' patience on appeals outcomes. 
First, a removal order from a harsher judge makes immigrants more likely to file an appeal, but only if they have a lawyer. More than half of all immigrants with lawyers appeal if they lose before the immigration judge, while only $3 \%$ of immigrants without lawyers appeal.62 Moreover, immigrants with lawyers are sensitive to the harshness of the immigration judges, whereas immigrants who file appeals pro se are not.

The left panel of Figure 2 shows a scatterplot of judges' relief rates and the appeal filing rates from their decisions. When immigrants have lawyers, they are more likely to appeal harsh judges' decisions. But when immigrants lack lawyers, they rarely appeal, regardless of how harsh their immigration judge was. In Figure 2, the dashed line, which shows represented immigrants, slopes downward: the higher the immigration judge's relief rate, the less likely that a represented immigrant will appeal a removal order. By contrast, the solid line, which shows unrepresented immigrants, is nearly flat: the immigration judge's harshness does not affect whether immigrants without lawyers decide to appeal.

Second, as expected, the government, which always has a lawyer, more often appeals the relief decisions of generous judges. The line in the right panel of Figure 2 slopes upward, showing that the higher the immigration judge's relief rate, the larger the chance that the government will appeal. However, government appeals are rare no matter what the immigration judges decide: they only appeal in about $3 \%$ of cases in which the immigration judge grants the respondent permission to remain in the United States.

Figure 2: Representation, Relief Rates, and Appeal Filings
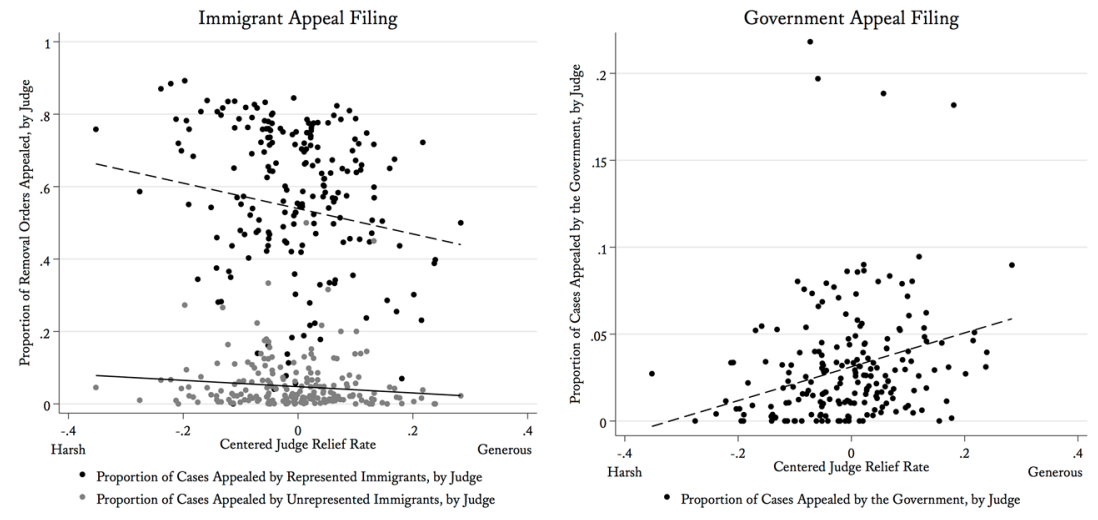

62 I categorized an immigrant as having a lawyer if a lawyer entered an appearance at any time during her case. 
These patterns persist in regression models that control for differences in case characteristics (such as nationality and immigration charges) across judges.63 The generosity of the immigration judge has a large and highly significant effect on whether represented immigrants appeal. For each ten percentage point decrease in a judge's relief rate within the same court, an immigrant with a lawyer is three percentage points more likely to file an appeal. The government's filing behavior follows a similar pattern but in reverse: the more generous the immigration judge, the more likely the government is to appeal. For each ten percentage point increase in a judge's relief rate, the government is less than one percentage point more likely to appeal.64 Still, this difference is statistically and perhaps also substantively significant given the low incidence of government appeal-again, the government appealed in only about three percent of cases during this period.

In other words, the patterns in Figure 2 are expected, with one exception: immigrants without lawyers are not sensitive to the harshness of the judge who ordered them deported. Unrepresented immigrants rarely appeal, regardless of whether their immigration judge is harsh or generous. If unrepresented immigrants are competently representing themselves, this result is surprising: those who are ordered deported by a harsh judge should be more likely to realize that they have a chance on appeal. In practice, however, unrepresented immigrants may not be well informed about the legal merits of their cases, so perhaps it is not surprising that their likelihood of appeal does not reflect the harshness of the immigration judge.

Patterns in appeal success, however, are different: immigrants appealing the removal order of a harsh judge are no more likely to win their appeal than those appealing from a relatively generous judge. This is surprising and troubling, and it likely reflects the fact that many of the removal orders of harsh judges evade scrutiny. Part IV explains this lack of scrutiny in more detail.

When the government appeals, by contrast, the pattern is the expected one: the government is more likely to win an appeal from a judge with a higher relief rate. Figure 3 shows these results. Moving from left to right (from harsher to more generous judges), the government's chance of winning an appeal rises sharply. Immigrants' chances of winning appeals, by contrast,

63 More details on these fixed effects regressions are provided in the Appendix, Section B, infra. These results are also robust to the exclusion of outliers. The results in Figure 2 persist when excluding (1) judges before whom represented immigrants appeal fewer than $40 \%$ of cases in the left panel, and (2) judges before whom the government appeals more than $10 \%$ of cases in the right panel.

64 Whether one describes the result as statistically significant depends on whether one prefers Model (3) in Table 7 in the Appendix, Section C, infra. Model (3) includes immigrant representation, along with an interaction term for representation and judge relief rate. 
are relatively flat. The BIA is no more likely to reverse the removal orders of harsh than of generous judges. 65

Figure 3: Asymmetrical Reversal Patterns on Appeal
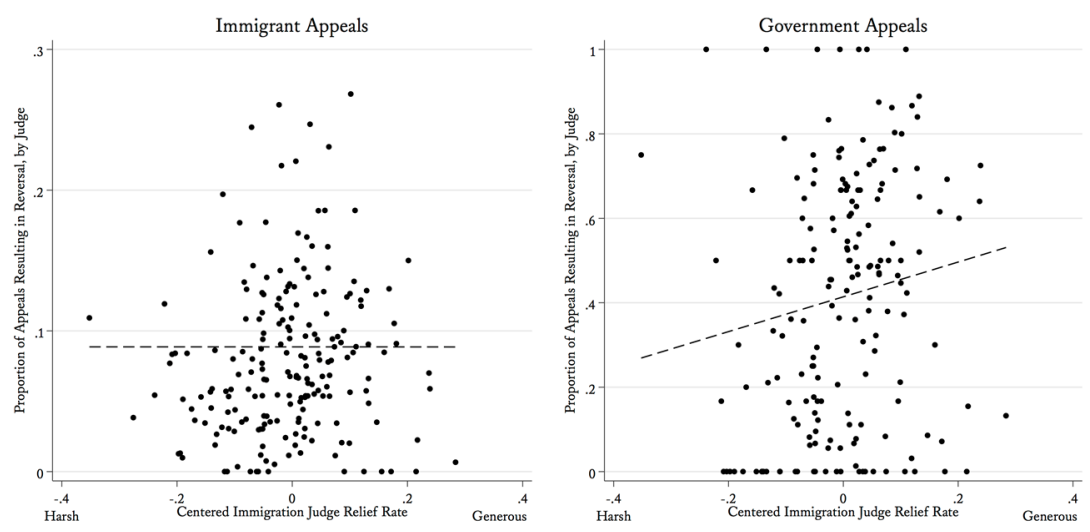

So far, I have shown the effects of immigration judges' harshness separately for appeal filings and appeal decisions. What is their combined effect? In other words, how does the harshness of the immigration judge affect the chance that the immigrant or the government will both file an appeal and win reversal of the judge's decision?

Immigration judges' varying generosity has no significant combined effect on whether immigrants appeal, but it does have an effect on whether the government appeals. Figure 4 shows this finding graphically. The trend line in the left panel of the figure for immigrants' rate of filing and reversal is nearly flat. The trend line in the right panel of the figure, by contrast, slopes upward: the more generous the immigration judge, the higher the probability that the government will both file an appeal and win.66

65 These results, too, are robust to the exclusion of outliers. For immigrant appeals, the lack of a pattern persists when judges with appeal win rates of below 0.01 and above 0.2 are excluded. For government appeals, the pattern persists when judges with appeal win rates of below 0.1 and above 0.9 are excluded.

66 All of these simple bivariate effects persist in regressions with control variables and court-year fixed effects. Consistent with the assumption that assignment of cases to judges is arbitrary with respect to the merits of the cases, including these variables does not substantially change the results, which are reported in Tables 6 to 11 in the Appendix, Section C, infra. Controlling for how much time immigration judges give immigrants to find a lawyer does alter the results. I discuss that finding in more detail in Part V, infra. 


\section{Figure 4: Overall Effect of Immigration Judge Generosity on Appeal to the BIA}
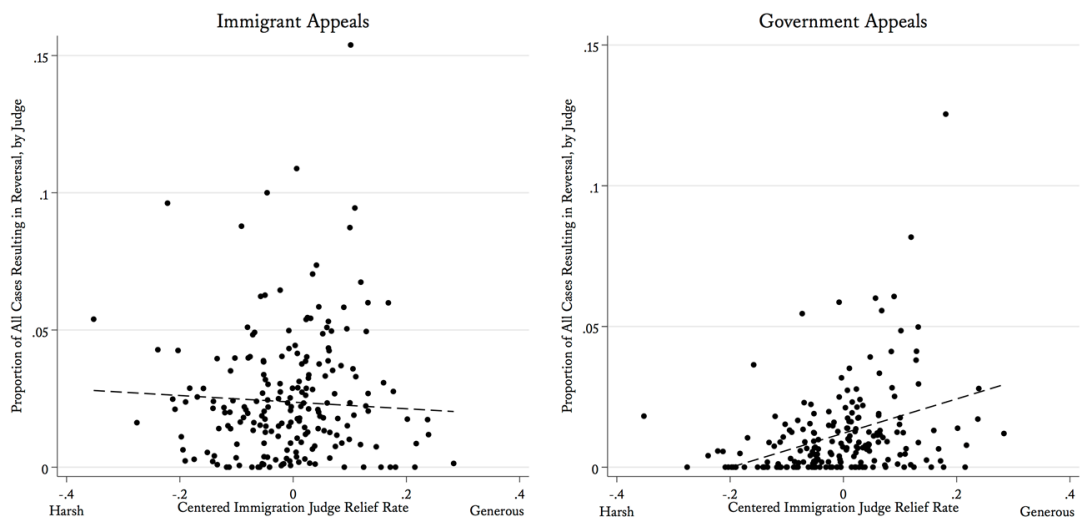

Overall, since government appeals make up fewer than $10 \%$ of all appeals, the BIA has only a marginal effect on uniformity across immigration judges. 67 In sum, the BIA is sensitive to uniformity across judges in only a small subset of all cases.

\section{B. Courts of Appeals}

The courts of appeals are no more successful than the BIA at promoting uniformity. This result is less surprising, however, since the courts of appeals defer more to the decisions of the BIA than the BIA defers to the decisions of immigration judges. 68 Petitions for review of final removal orders 69 are rare events, and reversal of the BIA's decisions is even rarer. Before the 2002 streamlining at the BIA,70 fewer than $5 \%$ of all cases resulted in a petition for review, and of those, fewer than 1 in 10 resulted in a remand. In other words, remands by a court of appeals occurred in fewer than 1 in 200 cases. 71

67 The government filed 4941 appeals during this period and won 1922 of them $(38.9 \%)$; immigrants, by contrast, filed 80,225 appeals and won 5863 of them $(7.3 \%)$.

68 See supra notes $26-31$ and accompanying text.

69 See 8 U.S.C. $\S 1101(\mathrm{a})(47)(\mathrm{B})$ (2012) (defining an "order of deportation" to include removal orders either that have been affirmed by the BIA or for which the period for an appeal has expired). Immigrants may only petition for review, however, if their order of removal became final after appeal to the BIA since they must have exhausted all administrative remedies to obtain judicial review. Id. $\S 1252$ (d)(1).

70 See infra Section IV.C.

71 These numbers increased dramatically after the 2002 streamlining reforms at the BIA, but petitions for review are nonetheless much rarer than appeals to the BIA. I discuss that streamlining and its effects, infra, Section IV.C. 
Immigration judges' generosity has no measurable effect either on filings or on outcomes before courts of appeals: immigrants ordered deported by harsh judges are no more likely to petition for review, and once they petition, are no more likely to win. The rarity of both petitions for review and remands may help explain this effect. Moreover, in order for an immigrant to petition a court of appeals for review, the immigration judge's removal order must have been affirmed by the BIA (or the immigration judge's relief decision reversed by the BIA), perhaps making that original judge's harshness less salient in the immigrant's decision about whether to appeal once again.72 Finally, the courts of appeals owe deference to the BIA; for many categories of discretionary relief, the agency's factual determination is unreviewable.73 These deferential standards of review may tie the hands of circuit judges, preventing them from promoting uniformity.

\section{Time, LAWyERS, AND SELECTION BIAS IN APPEALS}

Why do both the BIA and the federal courts of appeals fail to increase cross-judge consistency when immigrants appeal? Perhaps the lack of uniformity reflects the scant time and attention that the BIA and the courts are able to allocate to each case: many BIA decisions during this period were summary affirmances without legal reasoning,74 and staff attorneys at the courts of appeals decide many petitions for review. Yet the BIA is able to distinguish among cases appealed from more and less generous judges - when the government appeals. This might reflect a pro-government bias, but that explanation is also unsatisfying: although BIA members might well choose to reverse removal orders very rarely, one would expect them to reverse the removal orders of generous judges even more rarely than those of harsh judges.

The types of cases that reach the BIA and the circuit courts suggest a different explanation: many of the removal orders of harsh judges systematically evade scrutiny because such judges enter those orders early in immigration proceedings, before immigrants have time to find a lawyer or to file an application for relief. Without a lawyer or a relief application, immigrants rarely appeal, and the BIA and the courts therefore rarely have the chance to review their removal orders, which disproportionately come from harsher immigration judges.

72 See infra Tables 12-13. The results are generally consistent with the results at the immigration judge and BIA levels, but they should be interpreted with slightly more caution because the data may be less reliable. Since appeal dates are not reliably recorded, I cannot reliably isolate petitions for review that follow a particular BIA order.

73 See 8 U.S.C. $\S 125^{2}(\mathrm{a})(2)$ (listing issues that are not reviewable by a court of appeals); see also supra notes 27-29 and accompanying text.

74 See infra note 103 and accompanying text. 


\section{A. Time, Encouragement, and Access to Counsel and Relief}

Immigration judges differ dramatically in how often the immigrants before them file applications for relief or obtain lawyers and in the number of hearings those immigrants are granted before a final decision. Disparities across judges in relief application rates, although smaller than the final disparities in relief rates, span more than twenty percentage points in several courts. 75 The average disparity in representation rates across judges is higher still-actually even higher than the disparity in final relief rates. 76

These findings are surprising: Immigrants, not judges, are formally in control of whether they find a lawyer and apply for relief. However, immigration judges may influence representation and relief application rates in two ways: First, they can provide more or less time before requiring the immigrant to move forward with her case.77 Second, more speculatively, immigration judges may make encouraging or discouraging comments in the courtroom that influence immigrants' decisions about whether to proceed with their cases.

\section{Providing Time to Access Counsel}

Since the government does not provide lawyers to immigrants in removal proceedings, 78 immigration judges themselves advise immigrants of their rights. 79 Many immigrants $-42 \%$ in the time period that this Article

75 More precisely, the standard deviation of the immigration judge random effect in applications for relief is $7.2 \%$, which is smaller than the level of disparity in outcomes but still significant. The $95 \%$ confidence interval for this standard deviation covers $6.6 \%$ to $8.1 \%$. To count applications for relief, I included all cases in which the immigrant applied for at least one form of relief, apart from voluntary departure. See 8 U.S.C. $\$ 1229 \mathrm{c}(\mathrm{a})$ (permitting an immigrant to voluntarily depart the country instead of being ordered removed). Although voluntary departure is a form of relief, it serves a different purpose; some judges who otherwise do not strongly encourage relief applications might encourage applications for voluntary departure. The analysis here combines affirmative and defensive applications for asylum; as expected, replicating the analysis without including affirmative asylum applications yielded significantly higher levels of cross-judge disparity in applications for relief. I am grateful to Jaya Ramji-Nogales for suggesting that I try excluding affirmative applications as a robustness check.

76 The standard deviation of the random effect is $10.1 \%$, and the confidence interval covers $9.3 \%-11.4 \%$

77 See infra notes $80-88$ and accompanying text.

78 See 8 U.S.C. $\S 1229 a(b)(4)(A)$ (2012) (affording aliens the right to counsel in immigration proceedings with the costs borne by the alien); Orantes-Hernandez v. Thornburgh, 919 F.2d 549, 554 (9th Cir. 1990) (“A $]$ liens have a due process right to obtain counsel of their choice at their own expense.”).

79 Immigration proceedings are civil proceedings that take place within the EOIR, a division of the Department of Justice; immigration judges are appointed by the Attorney General. See 8 U.S.C. $\S 1101(\mathrm{~b})(4)$ (defining "immigration judge" as an attorney appointed by the Attorney General to serve within the EOIR); Eagly \& Shafer, supra note 46, at 10-11 (describing the structure of American immigration courts). Although they cannot be fired without cause, they are not administrative law judges under the Administrative Procedure Act (APA), Ramji-Nogales et al. (2007), supra note 39, at 380, and their decisions therefore do not qualify as formal adjudications 
considers-never find a lawyer, often because they cannot gather sufficient funds soon enough to employ one. At the initial master calendar hearing, which nearly always is a group hearing in which judges spend a few minutes on each case, immigration judges are required to tell immigrants that they have a right to a lawyer at their own expense. 80 Judges must also give unrepresented immigrants a reasonable opportunity to find a lawyer.81 At this first hearing, an immigrant who lacks a lawyer can request a continuance in order to seek counsel.82 The judge must grant that first request for a continuance, but if the immigrant does not have a lawyer at the next hearing, the judge may either choose to grant another continuance if she finds there is "good cause" to do so 83 or force the immigrant to represent herself. 84 In practice, these

under the APA, which sets out procedures and standards of judicial review for such adjudications. See generally 5 U.S.C. $\S 554$ (2012).

808 C.F.R. $\S 1240.10(\mathrm{a})(1)(2015)$.

81 See id. $\S 1240.10(a)(2)$ (requiring immigration judges to advise immigrants on the availability of free and other legal services in the area); see also Leslie v. Attorney Gen. of the U.S., 611 F.3d 171, 180 ( $3 \mathrm{~d}$ Cir. 2010) (finding that a failure of an immigration judge to advise a respondent of his right to attorney warranted reversal even without a showing of prejudice); EXEC. OFFICE FOR IMMIGRATION REVIEW, U.S. DEP'T OF JUSTICE, IMMIGRATION COURT PRACTICE MANUAL $\S 4.15(\mathrm{e})$ (2016), http://www.justice.gov/sites/default/files/pages/attachments/2016/02/04/practice manual_-_02-08-2016_update.pdf [https://perma.cc/Q2DU-DVLU] [hereinafter IMMIGRATION COURT PRACTICE MANUAL] (describing the purposes of master calendar hearings, including advising the respondent of her right to an attorney or other representative).

82 See Immigration COURT PRActice Manual, supra note $81, \S 4.15$ (g) ("[T] he respondent may request that the Immigration Judge continue the proceedings to another master calendar hearing to give the respondent an opportunity to obtain representation.").

838 C.F.R. $\S \S 1003.29$, 1240.6; see also Hernandez-Gil v. Gonzales, 476 F.3d 803, 807 (9th Cir. 2007) (noting that "the [immigration judge] must inquire whether there is good cause to grant petitioner more time to obtain counsel" when the petitioner does not waive her right to counsel).

84 See Immigration COURT Practice MANUAL, supra note $81, \S 4.15(\mathrm{~g})$ ("If the proceedings are continued but the respondent is not represented at the next master calendar hearing ... [ $\mathrm{t}$ ]he Immigration Judge may decide to proceed with pleadings at that hearing or to continue the matter again to allow the respondent to obtain representation."). A more detailed explanation follows the basic description of rights if a lawyer is not present to waive the respondent's right to that explanation. See 8 C.F.R. $\S 1240.10$ (a) (setting forth what an immigration judge must do at a hearing in which a respondent is not represented); IMMIGRATION COURT PRACTICE MANUAL, supra note $81, \S 4.15$ (i)(i) (noting that the respondent should be prepared "to request or waive an explanation of the respondent's rights and obligations in removal proceedings"). Among other things, the judge must explain the contents of the Notice to Appear. Id. $\S 1240.10(a)(6)$. This document includes a court date and location as well as immigration charges-the reasons that the government believes that the immigrant is in the country illegally. 8 U.S.C. $\S 1229$ (a)(1) (2012); IMMIGRATION COURT PRACTICE MANUAL, supra note $81, \S 4.2(\mathrm{a})$. These are formally known as grounds of inadmissibility (lack of permission to enter the United States) and deportability (lack of permission to stay in the United States). See 8 U.S.C. $\S 1182$ (2012) (listing grounds of inadmissibility); id. $\S 1227$ (listing grounds of deportability). Among the most common charges are entry without inspection (crossing the border without authorization), overstaying the period of a visa, or committing a crime. See Sara Morando Lakhani, Producing Immigrant Victims' "Right" to Legal Status and the Management of Legal Uncertainty, 38 LAW \& SOC. INQUIRY 442, 444-45 n.9 (2013) (listing entry without inspection and criminal acts involving moral turpitude or drugs as commonly 
requirements leave judges wide discretion, particularly in their decisions about how long to allow immigrants to continue looking for a lawyer. Some judges grant continuances freely; others grant only one or two in each case. 85

As a result, the length of proceedings varies significantly across immigration judges. 86 These differences are large: in some courts, the average length of a proceeding differs between some judges by more than two years. ${ }^{87}$

Additional time helps immigrants in several ways. Finding a lawyer and applying for relief are difficult tasks, especially for nonnative English speakers. Some lawyers may be busy; others may be unaffordable. More time increases the likelihood that an immigrant will secure a lawyer. Moreover, the longer the continuance, the more time the immigrant has to save enough money to pay for a lawyer. 88

The left panel of Figure 5 shows that judges who agree to more hearings per case are also more likely to hear cases in which immigrants have lawyers. Of course, lawyers might prolong cases by more frequently requesting continuances. The right panel of Figure 5 addresses that concern, showing that the judges who decide more cases with lawyers are also more likely to have lawyers enter an appearance later in proceedings. 89

applied inadmissibility grounds); Jan Ting, Immigration Law Reform After 9/11: What Has Been Done and What Still Needs To Be Done, 17 TEMP. INT'L \& COMP. L.J., 503, 506 (2003) (stating that the most commonly applied ground for deportation is overstaying a temporary nonimmigrant visa).

85 The denial of a continuance to seek representation may constitute a constitutional due process violation or a violation of the statutory right to counsel, but generally "[a]n [immigration judge] has wide discretion to manage his or her docket." Al Khouri v. Ashcroft, 362 F.3d 461, 464 (8th Cir. 2004). More generally, the Ninth Circuit, "[a]bsent a showing of clear abuse, typically do[es] not disturb an [immigration judge]'s discretionary decision not to continue a hearing," but it also does not "allow a myopic insistence upon expeditiousness to render the right to counsel an empty formality." Biwot v. Gonzales, 403 F.3 1094, 1099 (9th Cir. 2005) (quoting Ungar v. Sarafite, 376 U.S. 575, 589 (1964)). This standard leaves courts of appeals with some discretion to decide whether a continuance should have been granted. As I will argue below, however, the courts of appeals cannot reasonably monitor the behavior of immigration judges in granting continuances, since courts of appeals hear a small and skewed sample of cases. See infra note 109 and accompanying text.

86 The standard deviation of the judge-random effect is 1.1 hearings, and the $95 \%$ confidence interval covers 1 to 1.2 hearings. This means that judges hearing about a third of cases grant or deny one more or one fewer continuance than the mean.

87 See infra Figure 5 (showing the large variance across judges in time to a lawyer's entry of appearance).

88 Recall that I do not consider detained cases; continuances in those cases raise different concerns, since detention is costly both to detainees and to the government. See U.S. Gov'T ACCOUNTABILITY OfFICE, GAO-15-26, Alternatives tO DETENTION: IMPROVED DATA COLLECTION AND ANALYSIS NEEDED TO BETTER ASSESS PROGRAM EFFECTIVENESS 18-19 (Nov. 2014), http://www.gao.gov/assets/670/666911.pdf [https://perma.cc/CSW8-DJ7M] (estimating that the average cost of detaining an immigrant is $\$ 15^{8}$ per day).

89 When a lawyer enters an appearance, the date of the entry is recorded-albeit with some measurement error-in the Case Access System for EOIR database (CASE). NINA SIULC ET AL., VERA Inst. OF Justice, LEgAL ORIENTATION PROGRAM: EVAluATION AND PERFORMANCE AND OUTCOME MEASUREMENT REPORT, PHASE II, at 74, 83-84 (May 2008), http://www.vera.org/ 
If differences in the average number of hearings across judges were caused mostly by lawyers' requests for continuances, we would expect the opposite pattern-that immigrants with lawyers who entered their appearances immediately would receive more hearings. In other words, lawyers tend to enter their appearances later before judges who allow respondents more time to search for a lawyer.

Figure 5: Time and Representation
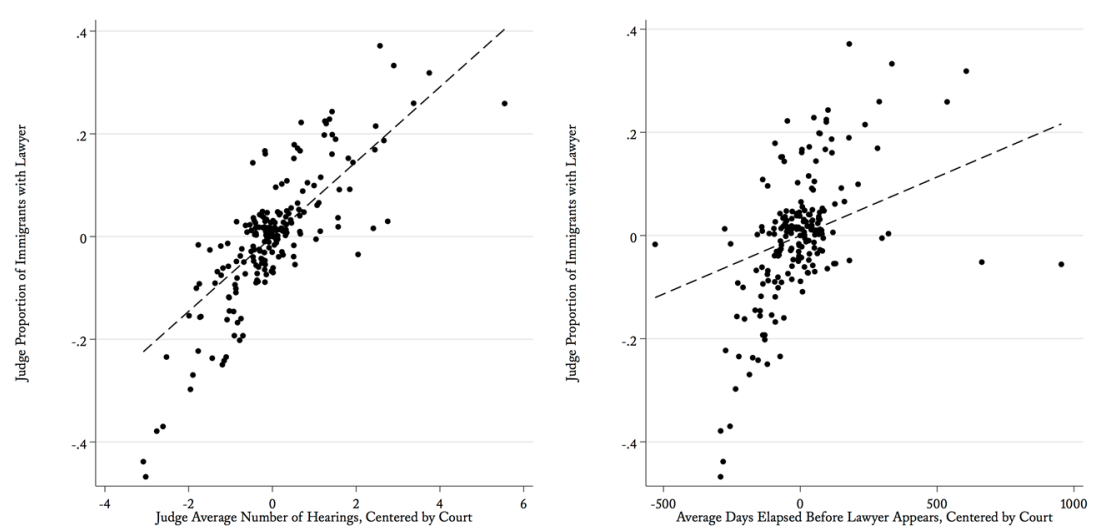

\section{Influencing Immigrants' Litigation Strategy}

Judges may also encourage or discourage immigrants from pressing their cases. All judges must inform immigrants of their right to a representative at

sites/default/files/resources/downloads/LOP_evalution_updated_5-20-08.pdf [https://perma.cc/EGL5$\left.{ }_{4} \mathrm{GM}_{3}\right]$. The form for entry of appearance is the Form EOIR-28. Notice of Entry of Appearance as Attorney or Representative Before the Immigration Court, U.S. DEP'T OF JUSTICE, http://www.justice. gov/sites/default/files/pages/attachments/2015/07/24/eoir28.pdf [https://perma.cc/BM2S-TE79] (last updated Dec. 2015). The number of days between the date of the EOIR-28 and the date of the Notice to Appear is therefore a measure of how late in the proceeding an immigrant found a lawyer. If an immigrant gets a new lawyer, that lawyer must once again file an EOIR-28 form, IMMIGRATION COURT PRACTICE MANUAL, supra note 81, § 2.2(i)(i), and the new date overrides the old one, SIULC ET AL., supra, at 83-84. In addition, since some lawyers refile EOIR-28 forms after their first appearances, in some cases this date may not reflect the initial date of appearance. Id. To be confident that EOIR-28 dates do not simply reflect the length of represented proceedings, and that the length of proceedings in fact matters on appeal, I replicated these results with new hearing-level data (obtained after the submission of this article) from EOIR. Using these hearing-level data to obtain an estimate of when a lawyer first appeared, I found that the correlation between judge representation rates and patience is slightly weaker-perhaps reflecting overwriting of EOIR-28 dates-but that the positive correlation persists, and the key results in the appeals regressions are robust to a hearing-level measure (not shown). Unsurprisingly, the two measures are highly correlated. 
no government expense, 90 but informal courtroom demeanor may make some judges more encouraging than others. Judges may also influence whether respondents find a lawyer in another way: by deterring lawyers from accepting cases in front of them. For example, lawyers in San Francisco and Los Angeles have said that they turn down cases assigned to some particularly harsh judges. ${ }^{91}$

Although all immigration judges are required to inform immigrants of any possible relief and to give them a chance to apply for it,92 judges retain discretion in how they give this advice. Some judges may be more diligent than others in asking questions that might help them find out that an immigrant is eligible for relief. Moreover, some judges may be more encouraging than others when informing immigrants that they can apply for relief. For example, while observing immigration court proceedings, I saw one judge inform potential asylum applicants that their own testimony would count as evidence, and that they could proceed with their applications for relief even if they were not able to bring other forms of evidence. Two other judges, by contrast, simply informed immigrants that they had the right to present evidence but said nothing further, leaving some immigrants to wonder whether they had a chance of success without presenting witnesses or documentary evidence.

Unrepresented immigrants also depend on judges to provide basic information about relief applications. For example, the asylum application form must be filed with the immigration court in English, and the first three pages must be sent to a U.S. Citizenship \& Immigration Services center.93 However, when distributing the application to unrepresented immigrants, some judges do not mention the mailing requirement. 94 When an immigrant appears for a hearing on the application and has failed to fulfill this requirement, the judge can refuse to adjudicate the application. $95 \mathrm{~A}$ judge has similar discretion if parts of the application are not filled out in English. For

90 IMMIGRATION COURT PRACTICE MANUAL, supra note 81, $\S 4.15(\mathrm{e})$.

91 See, e.g., LAWYERS' COMM. FOR CiVIL RightS OF THE S.F. BAY AREA, RESUlts OF THE 2014 SAN FRANCISCO IMMIGRATION JUDGE SURVEY 20 (2014) (on file with author) ("I will no longer take cases in front of [Judge Anthony S. Murry]. I know other lawyers who feel the same .... Murry is the perfect example of what is wrong with our immigration judicial system -if you draw him, you're out of luck."); Telephone Interview with Anonymous Immigration Attorney (Sept. 24, 2014) (on file with author) (explaining that her office does not accept cases in front of a particular judge in Los Angeles Immigration Court).

92 IMMIGRATION COURT PRACTICE MANUAL, supra note $81, \S 4.15(\mathrm{~g})$.

93 U.S. CitizenSHIP \& IMMIGRATION SERVS., U.S. DEP'T OF HOMELAND SEC., I-589, APPLICATION FOR ASYLUM AND FOR WITHHOLDING OF REMOVAL: INSTRUCTIONS 4, 9 (2014), https://www.uscis.gov/sites/default/files/files/form/i-58ginstr.pdf [https://perma.cc/ZPX 3 -R7VK].

94 I observed immigration judges handing out I- 589 applications without mentioning this requirement. 95 U.S. CITIZENSHIP \& IMMIGRATION SERVS., supra note 93, at 9. 
example, in one case I observed, a judge refused to accept a completed I-589 form because parts of the form were filled out in Spanish. 96

The same judges who allow more time for immigrants to find lawyers and complete their applications for relief are, on average, more likely to allow immigrants to remain in the country. Table 2 summarizes these relationships using a correlation matrix. The strongest correlations are those between judges' representation rates (the percentage of cases a judge hears with lawyers), relief application rates, and average numbers of hearings. These strong correlations are expected, since relief applications and lawyers are likely both consequences of additional time. The correlations between these three variables and judges' final relief rates are weaker by comparison, but are still strong.

Table 2: Correlation Matrix

\begin{tabular}{|c|c|c|c|c|}
\hline & $\begin{array}{l}\text { Relief } \\
\text { Rate }\end{array}$ & $\begin{array}{c}\text { Representation } \\
\text { Rate }\end{array}$ & $\begin{array}{c}\text { Relief } \\
\text { Application } \\
\text { Rate }\end{array}$ & $\begin{array}{c}\text { Average } \\
\text { Number } \\
\text { of } \\
\text { Hearings }\end{array}$ \\
\hline Relief Rate & 1 & & & \\
\hline Representation Rate & 0.28 & 1 & & \\
\hline Relief Application Rate & 0.28 & 0.56 & 1 & \\
\hline Average Number of Hearings & 0.37 & 0.73 & 0.36 & 1 \\
\hline
\end{tabular}

In sum, the results demonstrate that assignment to an immigration judge affects not only final outcomes, but also important intermediate outcomes. These outcomes in turn affect which immigrants choose to appeal.

\section{B. Selection Effects on Appeal}

Part III revealed that the BIA's uniformity-promoting effect exists only for appeals by the government, which constitute only a small fraction of all appeals, and that courts of appeals' decisions do not promote cross-judge uniformity at all. 97 These findings are easier to understand if cross-judge disparities partly reflect early decisions about continuances and relief applications. These early decisions are largely unreviewed, since immigrants who do not apply for relief or who do not have a lawyer very rarely appeal their deportation orders. Only

96 In that case, the judge granted a six-week continuance to allow the detainee to start over and complete the full form in English. This, however, was a detained case, so a continuance meant a longer stay in immigration detention. In the quantitative analysis here, I consider only nondetained cases, in which continuances do not lead to detention and only defer possible removal (or relief).

97 See supra Sections III.A, B. 
$5.9 \%$ of all appeals are from immigrants without lawyers and only $4.1 \%$ of all appeals are from immigrants who did not apply for relief.

In other words, the lack of uniformity, despite appeals, reflects two competing forces. Although immigrants are less likely to appeal the removal orders of more generous judges - that is, judges who grant relief more often - they are more likely to appeal the decisions of judges who give them time to find a lawyer, even though average case length and generosity are correlated. Generous judges allow immigrants to find lawyers, and therefore to appeal if they are ordered deported.

Because there are relatively few appeals from harsh judges, the BIA does not review many of the cases in which an order of removal reflected unusual harshness, and it therefore cannot correct errors in those cases. By contrast, the government only appeals when an immigrant has been granted relief (or, less commonly, termination).98 A generous judge's decisions to allow more time are reflected in her relief decisions, and the full record goes up on appeal. A judge's errors in granting relief are therefore always in the record on appeal, but a judge's denial of a continuance to seek counsel rarely comes before the BIA because immigrants without lawyers almost never appeal.

The data confirm this effect: as the average number of days before a lawyer makes a first appearance increases, the proportion of that judge's cases that are appealed by immigrants likewise increases, as well as the proportion of cases that are ultimately reversed. 99

Regression analysis supports the same conclusions. Tables 6 and 8 in Appendix, Section C, provide regressions with immigrant filing decisions and outcomes before the BIA as the dependent variables. Table 6 shows that immigrants are more likely to appeal the decisions of harsher judges but are simultaneously more likely to appeal the decisions of judges who give them more time to find a lawyer, even though those judges are on average more generous. Table 8 shows that judges' harshness has little effect on appeal outcomes, but that faster judges - those who allow more time for immigrants to find a lawyer-are far less likely to be reversed than slower ones.

Finally, the same pattern persists for petitions for review. Immigrants whose cases were originally decided by a slower judge are more likely to file a petition for review and slightly more likely to win. 100

This persistent correlation-between judges' willingness to give immigrants time to find lawyers and the likelihood that immigrants both

98 See 8 C.F.R. $\S 1239.2$ (f) (2015) (explaining termination of removal proceedings).

99 See infra Table 1.

100 The effect on filing behavior is much stronger than the effect on final outcomes; regressions with control variables suggest that there may be some small effect. Tables 10 and 11 show these patterns using multiple regression. 
appeal and win reversal-helps explain why neither the BIA nor the courts of appeals reverse more removal orders from harsh judges: many meritorious cases are simply never appealed.

\section{2002 Streamlining at the Board of Immigration Appeals}

Policy changes may also have contributed to the BIA's failure to promote uniformity. After drastic streamlining at the BIA in 2002, the BIA began reversing the decisions of generous judges more often, regardless of whether the immigrant or the government appealed.101 Indeed, before this streamlining, the BIA did have a slight uniformity-enhancing effect for appeals by immigrants. However, after 2002, the BIA's more cursory review, coupled with the selection problem in appeals, eliminated the effect entirely.

The BIA's 2002 streamlining dramatically changed its procedure for deciding cases. ${ }^{102}$ Most crucially, the BIA began to allow single members to make decisions and to issue summary affirmances-one sentence orders affirming the decisions of the immigration judge without any reasoning. 103

Immigration scholars and advocates have argued that these policy changes had important negative effects. For example, Margaret Taylor contends that the streamlining "greatly reduced [the BIA's] role of promoting uniformity and policy consistency through precedent decisions." 104 The quantitative evidence suggests that Taylor was partly right: the BIA appears to have become less sensitive to the harshness of immigration judges when immigrants appealed but more sensitive to their harshness when the government appealed. Another way of putting this is that the BIA simply started reversing the decisions of generous judges more often, even when those judges had ordered an immigrant removed and the immigrant appealed.

In cases appealed after March 2002, outcomes became more uniform when the government appealed and less uniform when immigrants appealed.105 That effect reflected the actions of both the BIA and of litigants. Immigrants, whose lawyers were no doubt aware of the BIA's change in policy and likely noticed that their chances of winning some appeals had gone down, began to appeal harsh and generous judges' removal orders at more similar rates. At the same time, as these lawyers seemed to anticipate, the BIA stopped reversing the

101 See generally Board of Immigration Appeals: Procedural Reforms to Improve Case Management, 67 Fed. Reg. 54,878 (Aug. 26, 2002) (codified at 8 C.F.R. pt. 3).

102 Id.

$103 \mathrm{Id}$. at $54,88 \mathrm{o}$. The BIA initially introduced a pilot streamlining program two years before. For details on its rollout, see Ramji-Nogales et al. (2007), supra note 39, at 350-53.

104 Margaret H. Taylor, Refugee Roulette in an Administrative Law Context: The Déjà Vu of Decisional Disparities in Agency Adjudication, 6o STAN. L. REV. 475, 489 (2007).

105 See infra Table 14. 
removal orders of harsher judges as frequently. The government also started appealing more often the relief decisions of generous judges, and began winning more often. In other words, lawyers for immigrants and the government noticed the new patterns in decisions by the BIA and changed their behavior accordingly. Table 14 summarizes these findings with regression results. 106

These results should be interpreted with caution: I compare appeals results before and after 2002, and the caseload around that time may have changed in ways that do not reflect the streamlining. Still, these findings offer some evidence that after 2002, BIA decisions less effectively promoted uniformity for immigrants appealing, but not for the government. Since immigrants appeal so much more often than the government, the net effect was that the BIA less effectively promoted uniformity. 107

These changes in the way the BIA treated the decisions of immigration judges accompanied a general trend toward fewer reversals of removal orders, regardless of the harshness of the immigration judge. The result was an enormous spike in the number of petitions for review to federal courts of appeals. Figure 6 shows this change. Before the streamlining, immigrants petitioned for review of approximately $5 \%$ of final removal orders issued by the BIA. After the streamlining, they petitioned for review of more than $25 \%$ of such orders - a $500 \%$ increase.

106 For these estimates, I used all data from the beginning of the EOIR case database until cases decided by the initial immigration judge before 2007. For the rest of the Article, I used data for cases beginning on or after January 1,1998 . That means that the vast majority of the appeals in those cases occurred after 2002; only a small number of cases went up on appeal quickly enough to be completed before the 2002 streamlining. In this Section, by using all the data in the database, I was able to capture the universe of appeals decided around 2002, as well as cases not appealed in that time period. This requires looking at cases subject to the pre-IRIIRA regime as well as those subject to IRIIRA; there is no other good way of creating these estimates, which I suggest interpreting with caution.

107 Disparities across immigration judges did not change significantly. 
Figure 6: Proportion of Final BIA Removal Orders Resulting in Petitions for Review

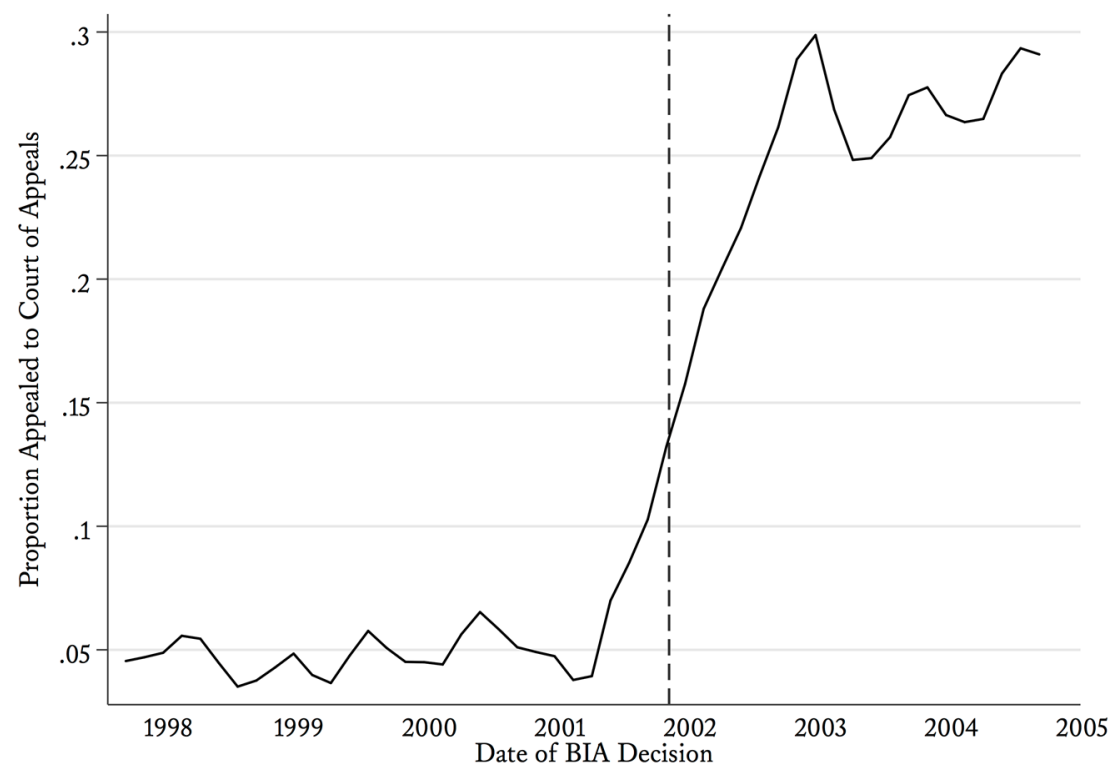

As the number of petitions for review grew quickly, the courts of appeals began more often vacating and remanding removal orders.108 Yet the 2002 reforms had no observable effect on the courts of appeals' sensitivity to the generosity of the initial immigration judge: they more often vacated the removal orders of both generous and harsh judges. This may reflect the fact that courts of appeals continued to see a biased sample of cases-those in which an immigrant found a lawyer before being ordered deported. It may also reflect the extent to which courts of appeals defer to BIA decisions.

In sum, examining time trends around the change in BIA policy provides an imperfect measure of the effects of the change, but it suggests that the BIA became much harsher after the 2002 streamlining and, as a result, also became somewhat less able to promote uniformity.

\section{IMPLICATIONS}

This Article's conclusion - that the immigration appeals process fails to promote uniformity because it rarely reviews removal orders issued by harsh judges to immigrants who lack lawyers at the beginning of their proceedings - has direct implications for policy and doctrine. First, the BIA

108 See infra Table 15. 
and the courts of appeals should alter their standards of review for the denial of a continuance. Of course, more continuances would make adjudications slower. I therefore suggest other reforms that could make adjudications fairer without slowing them. Relatively small changes in the relief application process-including translation of forms and simplification of practical requirements-could encourage immigrants to apply for relief, even without a lawyer. The BIA could also reduce disparities across judges by reviewing a random sample of cases in addition to those appealed by litigants. Last, and most ambitious, providing government-funded lawyers would likely not only help immigrants avoid removal, but would also reduce disparities across immigration judges and allow the BIA to supervise judges more effectively.

Beyond the context of immigration, this Article's findings have implications for administrative due process doctrine. The combination of adversarial and management models of case resolution in the immigration court system has perverse consequences, leading the BIA and the courts of appeals to consider and reverse a biased sample of cases. That problem is not unique to immigration cases. Since appellate judges hear a biased sample of cases in many areas of law, those judges may be unable to promote uniformity in other domains as well.

\section{A. Immigration Adjudications}

\section{Review of Denials of Continuances}

The BIA currently fails to promote uniformity partly because it does not adequately review immigration judges' decisions about continuances. A change in the BIA's standard of review for the denial of a continuance would be a first step toward solving this problem. Currently, "an Immigration Judge's discretionary decision denying a continuance will not be reversed on appeal unless the respondent establishes that the denial caused him actual prejudice and harm, and it materially affected the outcome of his case." 109 Ironically, the harm caused by denying a continuance is partly that it prevents a respondent who does not have a lawyer from obtaining one and eventually filing an appeal of an order of removal. Since few immigrants without lawyers appeal the denial of a continuance, those who do appeal are, on average, those less disadvantaged by the denial.

In other words, the evidence presented in this Article should lead the BIA to question its ability to judge whether a denial of a continuance materially affected the outcome of a case. Continuances affect an immigrant's ability to find a lawyer and therefore to demonstrate actual prejudice on appeal. By not requiring a showing of actual prejudice for reversal of a continuance and instead

109 Matter of Hashmi, 24 I \& N. Dec. 785, 787 (B.I.A. 2009). 
focusing on procedural aspects of the denial of a continuance, as described below, the BIA could better review judges' decisions about continuances. Notably, this would not only lead to more generous granting of continuances in the first place, but would also make decisions more consistent across judges, since it would raise the likelihood of appellate review.

The courts of appeals should also adopt a standard of review for the denial of continuances that does not require a counterfactual showing of the substantive importance of the continuance. In the Ninth Circuit, the immigration judge and the BIA are required to consider "factors including (1) the nature of the evidence excluded as a result of the denial of the continuance, (2) the reasonableness of the immigrant's conduct, (3) the inconvenience to the court, and (4) the number of continuances previously granted" when deciding whether to grant a continuance. 110 The last three factors of this standard are straightforward, but the first depends on an unrealistic counterfactual determination: the judge or the BIA may not be able to assess the nature of the evidence excluded as a result of the continuance if the continuance prevented the immigrant from entering new evidence. The same problem faces courts of appeals that require immigrants to show that they were prejudiced by the denial of a continuance in order to challenge a violation of the right to counsel.111 Once again, the immigrants who are able to provide compelling evidence that was excluded by the denial of a continuance are precisely those least harmed by that denial, since they eventually appealed.

A better standard for decisions would consider only the procedural elements: (1) whether the immigrant acted reasonably; (2) whether the immigrant inconvenienced the court; and (3) how many continuances the immigrant had already received. The courts of appeals could easily adopt such a standard.

Of course, a more immigrant friendly standard of review for the denial of continuances would have costs: more continuances mean less timely decisionmaking. Other compatible reforms, however, could improve timeliness while also reducing disparities.

\section{Practical Changes to Application for Relief Process}

Interviews and court observation suggest that many immigrants who are eligible for relief fail to apply for it-especially if they are assigned to a harsh immigration judge. A large and growing literature in behavioral economics has shown that small practical barriers can influence individuals' decisions,

110 An Na Peng v. Holder, 673 F.3d 1248, 1253 (9th Cir. 2012).

111 See Montes-Lopez v. Holder, 694 F.3d 1085, 1090-92 (9th Cir. 2012) (describing a circuit split on the question of whether a petitioner must show prejudice in order to challenge a violation of the right to counsel in an immigration proceeding). 
with surprisingly important policy consequences.112 The current requirements for immigration relief set up a series of unnecessary and easily removable practical barriers. Consider, for example, the practical steps necessary to apply for cancellation of removal, which is available to immigrants whose removal would cause "exceptional and extremely unusual hardship" to a U.S. citizen or lawful permanent resident spouse, parent, or child.113 First, the eight page form must be filled out in English or must be accompanied by a certified English translation.114 Immigration courts provide oral translation during hearings 115 but not written translation of relief applications. Second, the immigrant must pay a $\$ 100$ filing fee or request a fee waiver from the immigration judge. 116 Third, the immigrant must serve on Immigration and Customs Enforcement (ICE) Assistant Chief Counsel (1) a copy of the filled out form and all supporting documents, (2) a fee receipt, (3) biometric appointment information, (4) a separate Biographical Information Form, and (5) a photograph. ${ }^{117}$ Fourth, the immigrant must provide all of these documents, along with a certificate showing service of them on the ICE Assistant Chief Counsel, to the immigration judge. 118

These requirements are burdensome, especially for a non-English speaking immigrant with few resources, and they are also unnecessary. The EOIR or ICE could reduce the burden in several ways. First, translation services for the application itself would make it accessible to immigrants without lawyers. Translation requires resources, but the immigration courts already provide translation services in court; translation of applications is a natural corollary. Second, several of the paperwork requirements are not necessary. The immigration courts could share copies of applications with ICE rather than requiring the immigrant both to serve a copy directly and to produce proof of

112 See, e.g., Richard H. THALER \& CASS R. SUNSTEIN, NUdGE: IMPROVING DECISIONS ABOUT HEALTH, WEALTH, AND HAPPINESS 8 (2008) (noting that selecting a good default option enlists "the gentle power of nudges"-policies that change behavior without legal coercion or economic incentives).

1138 U.S.C. $\S 1229 \mathrm{~b}(\mathrm{~b})(1)(\mathrm{D})(2012)$.

114 EXEC. OFFICE FOR IMMIGRATION REVIEW, U.S. DEP'T OF JUSTICE, APPLICATION FOR CANCELLATION OF REMOVAL AND ADJUSTMENT OF STATUS FOR CERTAIN NONPERMANENT RESIDENTS 4, http://www.justice.gov/eoir/eoirforms/eoir42b.pdf [https://perma.cc/RD9G-FS 55] (last updated July 2015).

115 IMMIGRATION COURT PRACTICE MANUAL, supra note 81, § 4.11.

116 EXEC. OFFICE FOR IMMIGRATION REVIEW, supra note 114, at 4.

117 U.S. Citizenship and ImMigration SeRVS., U.S. DEP’T OF HOMELAND SEC., INSTRUCTIONS FOR SUBMITTING CERTAIN APPLICATIONS IN IMMIGRATION COURT AND FOR PROVIDING BIOMETRIC AND BIOGRAPHIC INFORMATION TO U.S. CITIZENSHIP AND IMMIGRATION SERVICES 2, http://www.uscis.gov/sites/default/files/files/article/PreOrderInstr.pdf [https://perma.cc/6ZTV-8MBP] (last updated Sept. 5, 2013).

118 Id. 
such service. The courts could also reduce the filing fee or make it contingent on the success of the application.

Removing these practical barriers to relief applications would help immigrants who have meritorious claims but lack lawyers and English skills. Moreover, removing these barriers would promote uniformity: the complexity of the current requirements gives immigration judges more discretion about whether to accept an application for relief. Some judges may accept applications that come close to meeting these requirements; others may enforce the requirements strictly. Simplifying the requirements would therefore also reduce disparities across immigration judges.

\section{Review of Additional Cases}

The EOIR could also more directly amend the appeals process. A central shortcoming of that process is that the BIA hears a skewed sample of casesoverwhelmingly those from immigrants with lawyers who have filed relief applications. The BIA could address this bias by randomly selecting additional cases to review.119 Such random selection is foreign to the adversarial model of litigation and appeals, but not to administrative appeals: for example, the Social Security Agency's Appeals Council already employs random and selective sampling to choose cases for review. 120

The BIA could adopt a similar procedure with a special focus on the denial of continuances. It could randomly choose decisions on continuances-both denials and grants-for sua sponte review. Since these decisions typically follow from a short colloquy between the immigrant and the immigration judge, the BIA could use hearing transcripts to review many such decisions quickly-before the decisions exert practical effects. If the BIA were to review a substantial number of continuance decisions, immigration judges might begin to change their behavior to avoid reversal. Together with a change in the standard of review, such random appellate review could make immigration judges' continuance decisions more consistent.

119 This policy would, of course, entail arbitrary selection of some cases for additional procedural safeguards. If the policy succeeded in increasing consistency across immigration judges, however, that increased consistency would make the policy's random access to appeal itself less important.

120 See 20 C.F.R. $\S 404.969$ (b)(1) (2015) ("We may use random and selective sampling to identify cases involving any type of action (i.e., fully or partially favorable decisions, unfavorable decisions, or dismissals) and any type of benefits (i.e., benefits based on disability and benefits not based on disability). We will use selective sampling to identify cases that exhibit problematic issues or fact patterns that increase the likelihood of error. Neither our random sampling procedures nor our selective sampling procedures will identify cases based on the identity of the decisionmaker or the identity of the office issuing the decision."). 


\section{Adoption of Government-Provided Counsel for Immigrants}

Finally, this Article's findings provide additional reasons to support a program of government-provided counsel for immigrants. Over the past decade, the government has faced growing pressure, in the form of both litigation and advocacy, to provide lawyers for immigrants in removal proceedings. Immigrants' rights groups have successfully sued for the right to government-provided counsel for mentally ill respondents121 and a nationwide class action seeking representation for children facing deportation is currently pending. ${ }^{122}$ Advocacy efforts have recently been successful in obtaining universal representation for indigent, detained immigrants in New York City's immigration courts, with funding provided by private foundations and the New York City Council.123

Immigrants' rights advocates have typically argued that immigrants are unable to represent themselves effectively, citing descriptive statistics showing much higher win rates for represented than for unrepresented immigrants.124 For example, reports about immigration courts in New York City and Northern California have highlighted large disparities in deportation rates for detained immigrants with and without lawyers. ${ }^{125}$

This normative case for representation reflects two related injustices: the injustice of deporting an immigrant who might have valid claims for relief, and the injustice of treating immigrants with similar potential claims unequally because one has a lawyer and the other does not.

121 See generally Franco-Gonzalez v. Holder, No. CV-10-02211 DMG (DTBx), 2014 WL 5475097 (C.D. Cal. Oct. 29, 2014) (issuing a permanent injunction requiring the Attorney General to screen immigrants for mental illness and provide counsel to incompetent respondents).

122 See J.E.F.M. v. Holder, 107 F. Supp. 3d 1119, 1144 (W.D. Wash. 2015) (allowing the juveniles' request for classwide declaratory judgment to remain but dismissing the juveniles' request for classwide injunctive relief).

123 See Press Release, Vera Inst. of Justice, New York Becomes First Jurisdiction in Nation to Provide Universal Representation to Detained Immigrants Facing Deportation (June 26, 2014), http://www.vera.org/news/new-york-city-provide-universal-representation-detained [https://perma .cc/WNQ2-X779] (describing the City Council's allocation of $\$ 4.9$ million "to provide universal representation to any indigent immigrant detained and facing deportation").

124 See generally, e.g., Eagly \& Shafer, supra note 46.

125 See, e.g., N. CAL. COLLabOrative FOR IMMigrant Justice, ACCESS TO Justice FOR IMMIGRANT FAMILIES AND COMMUNITIES: STUDY OF LEGAL REPRESENTATION OF DETAINED IMMIGRANTS IN NORTHERN CALIFORNIA 18 (Oct. 2014), http://www.lccr.com/wp-content/ uploads/NCCIJ-Access-to-Justice-Report-Oct.-2014.pdf [https:/perma.cc/L8GJ-8ZAT] ("Detained individuals with lawyers were three times more likely to prevail in their removal cases than those without attorneys."); Steering Comm. of the N.Y. Immigrant Representation Study Report, Accessing Justice: The Availability and Adequacy of Counsel in Removal Proceedings, New York Immigrant Representation Study Report: Part 1, 33 CARDOZO L. REV. 357, 384 (2011) ("[P]eople who were represented and not detained at the time of case completion were ... [a]lmost six times as likely to obtain a successful outcome as those ... who were unrepresented."). 
This Article's findings offer three more normative reasons to provide counsel to those who cannot afford it. First, immigrants face unequal treatment because immigration judges differ in how easy they make it for immigrants to find counsel.126 Second, this disparate access to counsel also affects immigrants' access to the appeals process.127 Finally, judges' influence on immigrants' ability to access counsel also affects which cases immigrants appeal: unrepresented immigrants are unlikely to appeal no matter what, but immigrants with lawyers appeal more often when the judge who ordered their deportation is harsher than average.128 Government-provided lawyers would therefore increase equality in cases across judges, most immediately by equalizing the rate at which immigrants are represented, and, as a result, equalizing access to appeals.

This policy proposal, like the proposed simplification of the relief application process, has an additional advantage: removal proceedings need not be delayed so that an immigrant can search for a lawyer. The denial of continuances is normatively troubling because it prevents immigrants from finding a lawyer and building their case, not because it shortens cases. In fact, timeliness in adjudications is a due process value. Granting continuances is not a natural way of increasing the rate of representation. The government could increase that rate directly by providing lawyers and could simultaneously take measures to reduce the length of proceedings. This conclusion is consistent with (though not as strong as) the conclusions of a report authored by economic expert John Montgomery for the New York City Bar Association, which found that a program of government-provided representation could pay for itself, partly by reducing the number of continuances requested by immigrants. 129

In sum, this Article's empirical findings provide support for several straightforward doctrinal and policy changes, along with a new normative rationale for the government to provide lawyers to immigrants in removal proceedings.

126 See supra subsection IV.A.1.

127 See supra Section IV.B.

128 See supra Figure 2.

129 See Dr. John D. Montgomery, NERA Econ. Consulting, Cost OF COUnSEL IN IMMIgRATION: ECONOMIC ANALYSIS OF PROPOSAL PROVIDING PUbliC COUNSEL TO Indigent PERSONS SubJECT TO IMmigration REMOVAL ProceEdings 3 (2014), http://www.nera.com/content/dam/nera/publications/archive2/NERA_Immigration_Report_5.28.2 014.pdf [https://perma.cc/PHW6-VWK8] (contending that savings from reduced detention costs, legal orientation programs, transportation, and foster care would pay for most of the publicly funded counsel); see also supra note 88 and accompanying text. 


\section{B. Administrative Due Process}

These results and policy recommendations also contribute to a larger debate over how to protect due process rights in administrative adjudications. Administrative due process doctrine relies explicitly on the empirical assumption that adversarial procedures increase the accuracy of administrative hearings. In Goldberg v. Kelly, the Supreme Court found a constitutional right to a hearing before termination of welfare benefits, holding that such a hearing would further both the government's and the claimant's interest in an accurate eligibility decision.130 Although the Court has subsequently narrowed the Goldberg holding, this rationale for due process requirements persists. Mathews v. Eldridge established the contemporary procedural due process balancing test: to determine whether hearing procedures are constitutionally adequate, the Court considers (1) the importance of the private interest at issue, (2) the risk of error in the current procedure and the likely value of additional or alternative procedures, and (3) the government's interest in minimizing costs. ${ }^{131}$

The second Mathews factor typically requires courts to estimate the value of additional procedures. When reviewing decisions by immigration judges and the BIA, courts of appeals must not only decide whether a specific procedural safeguard increases the risk of error, but also whether the lack of that safeguard actually caused prejudice in the case before them.132

Measuring the error-reduction benefit of additional procedures is a difficult empirical task, which in practice leaves judges guessing. Still more worrying is that procedural deficiencies can systematically prevent appeals courts from hearing cases that are representative of the overall case pool. This Article has offered an example of this dynamic in immigration adjudications: denials of continuances not only prevent immigrants from raising substantive claims but also prevent them from appealing those denials by limiting their access to counsel.

The problem, however, is a more general one. Immigration adjudications combine inquisitorial and adversarial procedures. In an unrepresented removal hearing before an immigration judge, the procedure is largely inquisitorial.133

130 See 397 U.S. 254, 266 (1970) (finding that, because hearings serve the goal of reaching correct results, "the interest of the eligible recipient in uninterrupted receipt of public assistance, coupled with the State's interest that his payments not be erroneously terminated, clearly outweighs the State's competing concern to prevent any increase in its fiscal or administrative burdens").

131424 U.S. 319, 335 (1976).

132 See, e.g., United States v. Nicholas-Armenta, 763 F.2d 1089, 1091 (9th Cir. 1985) (holding that mass deportation hearings do not necessarily violate the Due Process Clause and that a group hearing did not cause prejudice to the petitioner).

133 See Fatma E. Marouf, Implicit Bias and Immigration Courts, 45 NEW ENG. L. REV. 417, 430 (2011) ("The Immigration and Nationality Act allows [immigration judges] to interrogate, examine, and cross-examine witnesses."). 
The immigration judge must provide the immigrant with information about the charges against her as well as possible forms of relief, and must advise the immigrant that she is entitled to be represented by counsel.134

If, however, the immigration judge fails to fulfill these inquisitorial responsibilities, an immigrant may seek relief through an appeal to the BIA. Yet that appeals process, although theoretically available to unrepresented immigrants, is in practice an adversarial procedure used almost exclusively by immigrants with lawyers.135 Immigration adjudications occupy a middle ground between administrative social welfare adjudications and criminal trials. Immigration courts employ procedures similar to those used to apportion social welfare benefits, such as social security disability insurance, but the penalty-banishment-more closely resembles a criminal sanction than denial of access to a welfare benefit.

Which set of procedural protections is appropriate? I do not attempt to resolve this question in my policy recommendations. Instead, I have proposed specific policy changes that draw on both criminal and administrative procedures. Government-provided counsel would make immigration courts look more like state criminal courts, but random selection of continuance decisions for review on appeal would make immigration adjudications look more like Social Security disability appeals. Both would make outcomes more consistent across judges.

More conceptually, the immigration appeals process faces problems similar to those identified forty years ago by Jerry Mashaw in his work on the concept of due process as a management problem.136 Mashaw argued that the purposes and nature of claims in social welfare adjudication systems render procedural and appeallate safeguards ineffective. 137 Mashaw's response to this conundrum was to reframe due process concerns in social welfare decisions as a management problem.138 Government agencies could ensure accuracy, fairness, and timeliness in adjudications by adopting nonadversarial procedural safeguards.139 Specifically, Mashaw advocated the adoption of quality assurance systems - nonadversarial accuracy checks. ${ }^{140}$

134 See supra notes $78-82$ and accompanying text.

135 See supra Figure 2.

136 See generally JERRY L. MASHAW, BUREAUCRATIC JUSTICE: MANAGING SOCIAL SECURITY DiSABILITY ClAIMS (1983); Jerry L. Mashaw, The Management Side of Due Process: Some Theoretical and Litigation Notes on the Assurance of Accuracy, Fairness, and Timeliness in the Adjudication of Social Welfare Claims, 59 CORNELL L. REV. 772 (1974) [hereinafter Mashaw, The Management Side of Due Process].

137 See Mashaw, The Management Side of Due Process, supra note 136, at 804 ("[T] he provision of formal procedural safeguards and appeal rights is inadequate in some contexts unless bolstered by a sound internal quality assurance program.").

138 Id. at $775-76$.

139 Id.

140 See generally id. 
That suggestion is very similar to my proposal that the BIA randomly select continuance decisions for review on appeal. In fact, the Social Security Agency uses its Appeals Council-the analogue to the BIA-to randomly evaluate cases, in a variation on a quality assurance system.141 The random selection procedure proposed here is therefore a simple form of a quality assurance system - an appeals procedure without litigant selection.

A quality assurance system would address the problem of selection bias in appeals - the fact that some litigants are more likely to appeal, regardless of the merits of their case. That problem is particularly severe in immigration court, where many litigants lack the resources to appeal, but the same problem necessarily exists in other mass adjudication contexts, raising similar research questions. Which Social Security disability and National Labor Relations Board cases, for example, are most likely to reach the courts? And how does that sample affect courts' ability to promote uniformity? I hope that this Article serves partly as a call for empirical research to begin answering these questions.

\section{CONCLUSION}

Many normative theories of appeal rely on appellate bodies' ability to create uniform outcomes. The immigration appeals process fails to promote at least one type of uniformity: smaller cross-judge disparities. This failure reflects the structure of initial immigration adjudications. Harsh immigration judges' removal orders are systematically less likely to be appealed.

Courts and scholars of administrative and immigration law have long debated whether agencies should take steps to limit the discretion of administrative judges and thereby reduce disparities. ${ }^{142}$ That controversy has centered on whether agency heads should be able to limit the discretion that judges exercise when they grant relief or issue a removal order.143 This Article shows that immigration judges make disparate decisions long before they exercise their discretion over relief claims: some are more likely to grant continuances than others, and are therefore more likely to allow immigrants to find a lawyer and apply for relief. Moreover, these disparities in early decisions help explain why the BIA and the courts of appeals are no more likely to reverse the deportation orders of harsh judges than those of generous judges: harsh

14120 C.F.R. $\S 404.969$ (b)(1) (2015).

142 See, e.g., Nash v. Bowen, 869 F.2d 675, 681 (2d Cir. 1989) (denying Social Security administrative law judge's claim that agency policies intended to reduce disparities violated their right to decisional independence under the Administrative Procedure Act); Taylor, supra note 104, at 490-95 (providing an overview of the controversy over decisional independence for Social Security administrative law judges).

143 See Taylor, supra note 104, at 481 (describing the "obvious tension" between increased oversight and the "decisional independence of agency adjudicators" that has "bedeviled administrative law from its inception"). 
judges partly reach their results by preventing an individual relief hearing with a lawyer, rather than by denying relief to immigrants who make it that far.

These two related empirical findings suggest policy prescriptions. It may be possible to reduce disparities without limiting judges' discretion, even over whether to grant continuances. Since continuances likely affect outcomes by helping immigrants apply for relief and find lawyers, providing immigrants with lawyers should reduce disparities. Providing lawyers to immigrants is already a priority for the immigrants' rights movement; 144 this Article simply provides an additional rationale for reform. Short of such dramatic reform, this Article proposes small, targeted policy changes: changing the standard of review for the denial of a continuances, making relief applications easier to file, and providing randomized review of immigration judges' continuance decisions. These small changes would begin to fix the immigration appeals process, taking a step toward fairer results in immigration court.

144 See, e.g., STUDY GROUP ON IMMIGRANT REPRESENTATION, NEW YORK IMMIGRANT REPRESENTATION STUDY, ACCESSING JUSTICE: THE AVAILABILITY AND ADEQUACY OF COUNSEL IN IMMIGRATION PROCEEDINGS 38 (2011), https://www.ils.ny.gov/files/Accessing\%20Justice.pdf [https://perma.cc/7EUR-6GZ8] (advocating "intense and widespread commitment across stakeholders" to address the "enormous scale" of the access-to-counsel problem); see also supra subsection V.A.4. 


\section{APPENDIX}

\section{A. Case Assignment}

To study the effect of judges' differing generosity, one would ideally assign cases randomly to judges. Although previous studies of cross-judge disparities have asserted that assignment to judges is random in practice, 145 I find that assignment is not random and consider the likely causes of the nonrandomness. Relying on interviews with lawyers and court personnel, evidence of case clustering, and the replication of results within a subset of the data in which assignment appears random, I argue that case assignment is arbitrary with respect to the merits of cases.

Previous work on disparities across immigration judges has relied on the immigration courts' own assertion that cases are randomly assigned to judges. ${ }^{146}$ Ramji-Nogales et al. also rely on these assertions as evidence of random assignment across asylum cases within the same immigration court and detention calendar, but they do not test the assertions.147 These assertions are inaccurate in two important respects. First, the subset of cases in which an immigrant has filed an asylum application is far from random. As I show below, the filing of a relief application is itself an important result of judge assignment. Filing an I-589 form in English is a difficult administrative task for some unrepresented immigrants, and a judge can make immigrants aware of the possible relief and encourage them to apply for it.148 A judge can also be more or less generous in granting continuances to allow an immigrant to gather evidence and complete the application. ${ }^{149} \mathrm{~A}$ full analysis of asylum disparities therefore should consider both asylum filing rates and asylum success rates. 150

Second, assignment is not random, although I find that deviations from random assignment are small and not highly correlated with the merits of the

145 See, e.g., Ramji-Nogales et al. (2007), supra note 39, at 332 (noting that "nearly all [asylum] cases are assigned randomly to the judges").

146 See, e.g., id. at 326 n.52 (citing, without questioning, U.S. GOV'T ACCOUNTABILITY OFFICE, EXEC. OfFICE FOR IMMIGRATION REVIEW, CASELOAD PERFORMANCE REPORTING NEEDS IMPROVEMENT 17 (2006), for the proposition that immigration cases are largely assigned through an automated system, with narrow exceptions for unaccompanied juvenile cases, cases that were previously assigned a judge in the same immigration court, and judges with heavy caseloads).

147 See generally Ramji-Nogales et al. (2007), supra note 39. The authors also address possible differences in caseload by looking at one nationality at a time. This strategy reduces the likelihood of bias, but it does not solve the problem that relief application rates vary across judges as well. In addition, looking at one nationality at a time reduces the number of cases heard by each judge and raises the chances that disparities reflect statistical noise rather than judges' attitudes. To avoid this risk, I use a measure of disparity that explicitly accounts for such random variation with a confidence interval.

148 See supra notes 93-96 and accompanying text.

149 See supra note 85 and accompanying text.

150 Addressing these issues requires data on all forms of relief, which were not available to Ramji-Nogales et al., but are recorded in the full EOIR database used here. 
cases. In assessing cross-judge disparities, the key danger is that some judges hear more meritorious cases than do others. If court administrators assign different judges easier or harder cases, then different rates of relief would reflect differences in caseload rather than in the actions of immigration judges. Alternately, if lawyers strategically direct their cases to particular judges, relief rates might reflect lawyers' actions.

In qualitative research on the assignment process, however, lawyers unanimously said that they were unable to affect which judge heard their cases and that they had not noticed systematic differences in types of cases across judges.151 They believed that assignment was random within groups of detained and nondetained immigrants at the same court.

These impressions from lawyers do not fully hold up in the data, however. To check for random assignment of cases to judges, I conducted balance tests below. If assignment is random, the proportions of each judge's cases from common nationalities and with certain immigration charges should be approximately equal within the same court. There are statistically significant differences across judges in nearly all courts during most of the period of study.

What might cause these differences across judges? No one I spoke with suspected deliberate manipulation of the process. For example, a former law clerk at one of the largest immigration courts was certain that the volume of cases and the difficulty of scheduling them all would prevent the administrative staff from implementing a deliberate assignment scheme.

In the absence of a deliberate scheme, what might lead to nonrandom patterns in case assignment? First, people are notoriously bad at implementing random assignment; when asked to choose numbers randomly

151 I spoke with attorneys and court personnel in Eloy, Arizona; Florence, Arizona; Los Angeles, California; San Francisco, California; New Orleans, Louisiana; Oakdale, Louisiana; and New York, New York. Note that this analysis excludes all detained cases, even the cases of those who were quickly released. Although assignment appears to be arbitrary within courts and nondetained/detained calendars, assignment is not arbitrary across detained and nondetained cases within each immigration court. For example, in the San Francisco immigration court, four judges routinely handle detained cases. Comparing the relief rates of those judges to the relief rates of colleagues who hear overwhelmingly nondetained cases would be deceptive, since relief rates for detained cases are lower on average. Isolating asylum cases would not solve this problem. Detained immigrants may have more reason than nondetained immigrants to apply for asylum; other forms of relief may be unavailable. More broadly, the Department of Homeland Security exercises discretion when it chooses whom to detain, and it may choose to detain immigrants whose cases inspire less (or more) sympathy than those whom it releases. Controlling for observable differences between detained and nondetained immigrants cannot solve this problem without the extremely strong assumption that detained and nondetained populations are similar in all the unmeasured ways that matter. For example, the EOIR data do not include socioeconomic information about immigrants. A model controlling for only the available variables must assume that these are the only ones that matter. 
in an experimental setting, they often fail.152 If administrators are asked to distribute cases randomly to judges, they may fail even if they make good faith attempts to do so. A seemingly random method-such as distributing cases by the last name of the immigrant-could lead some nationalities to be overrepresented or underrepresented. Other seemingly random methods might encounter similar pitfalls. For example, immigrants' Alien Numbers, which are used to identify their cases in immigration court, have some distinct patterns. Alien Numbers beginning with certain digits are associated with the immigration amnesty of the 1980 s, for example. 153 Since those immigrants were able to obtain green cards, they would only find themselves in immigration court after committing a crime. So an assignment scheme that relied on Alien Numbers might send a disproportionate number of criminal cases to certain judges.

Moreover, the process by which cases enter the immigration courts is itself not random, and that nonrandomness may affect case assignment. For example, many cases reach immigration court after workplace sweeps, and all the cases from a sweep may be assigned to one or a few judges. 154 Nonrandom patterns in workplace raids may therefore lead to nonrandom patterns in case type across judges.

None of these deviations from random assignment are directly observable in the data, but the data show that cases arrive in clusters, perhaps as a result of raids or arrests near the border. Figure 7 shows the number of immigrants charged with "entry without inspection" - a common immigration charge-by week over the period of study in the largest four immigration courts. The graph shows large week-to-week deviations in each court; cases of entry without inspection arrive in clusters. If cases are assigned to judges in rotation, then this clustering could contribute to the lack of random assignment.

152 See James E. Mosimann et al., Data Fabrication: Can People Generate Random Digits?, 4 ACCOUNTABILITY RES. 31, 45 (1995) (finding that experimental subjects often failed to generate a uniform distribution of digits when asked to choose numbers randomly).

153 This is based on interviews with immigration court clerks.

154 See Telephone Interview with a Los Angeles Immigration Attorney (Sept. 24, 2014) (on file with author) ("There was a big raid that we dealt with four or five years ago and we ended up getting the same three judges on it."). 
Figure 7: Clustering in Immigration Cases

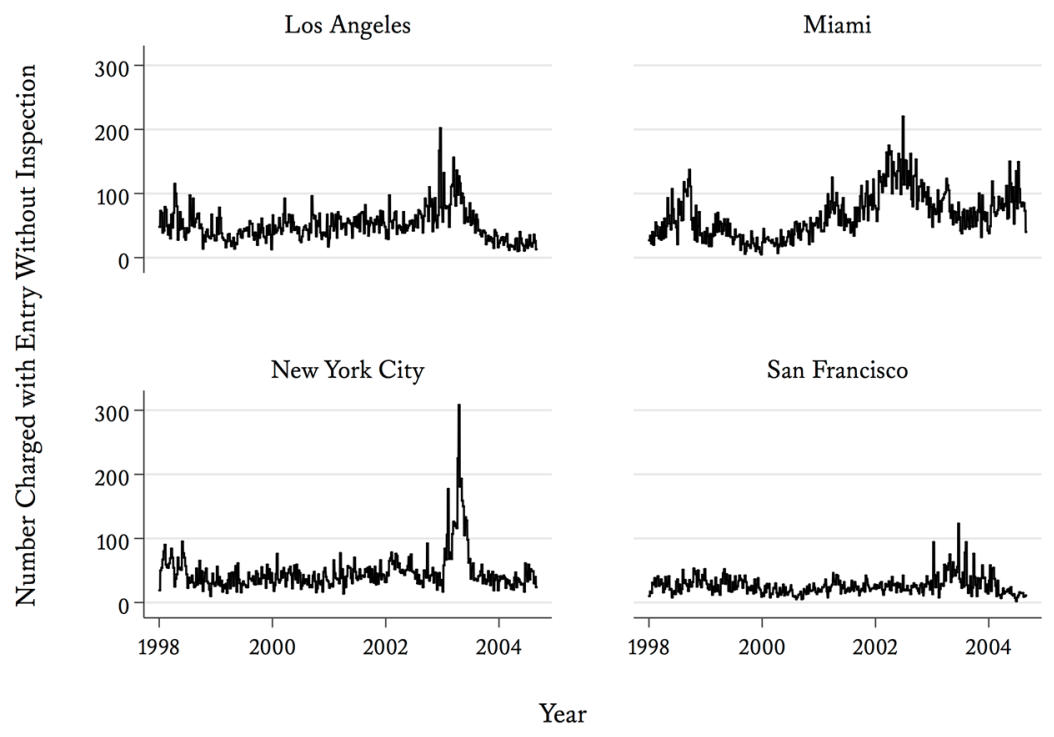

Even where significance tests reject the null hypothesis that case assignment is independent of judges, however, deviations from random assignment may be arbitrary with respect to the outcomes that matter-here, judges' decisions.

I began by checking balance on covariates. To check balance, I needed to identify case characteristics that are set prior to assignment to a judge, and that the judge cannot affect. Finding these characteristics requires attention to the practical course of a removal proceeding in immigration court.

First, the initial charges are determined before the judge hears a case. With some exceptions, an immigration proceeding begins with a Notice to Appear, issued by the Department of Homeland Security (DHS).155 EOIR records the immigration charges on the Notice to Appear in the CASE database at the outset of the proceeding. The charges recorded in the database generally do not change, even if DHS later drops or adds charges. 156

155 See supra note 84. No Notice to Appear is issued when an immigrant is subject to expedited removal, a procedure that bypasses immigration court unless the immigrant argues that she has a reasonable fear of persecution upon deportation and is therefore eligible for withholding of removal. In these cases, the reasonable fear issue is referred to immigration court, but no Notice to Appear is issued.

156 This makes the charge information in the database less reliable as a record of the final charges in a case, but it also means that different charges should be randomly distributed across judges if case assignment is random. 
Similarly, immigrants' personal traits precede judge assignment. The most obviously salient trait in immigration court is nationality, since nation of origin can directly affect the merits of immigration cases. Gender and age might, however, be important in less direct ways. Unfortunately, EOIR only began recording gender and age a few years ago; many of the cases with gender and age information are not yet completed.

These are, unfortunately, the only covariates in the CASE database that are definitively determined before the first hearing. Judges can subtly affect several other case characteristics that might otherwise be set before hearings. For example, the database includes the language of the hearings, and immigrants who are fluent in both English and another language may choose which language to use. Judges can affect this choice by urging immigrants more or less strongly to use an interpreter. Judges may also affect the likelihood that immigrants find lawyers and apply for relief, as I argue in the body of the Article.157

As a summary balance check, I performed chi-squared tests for independence between these four proportions and judge assignment within each immigration court for every three-month period between January 1, 1998, and August 31, 2004. If assignments were random, we would expect 95\% of the resulting $p$-values to be greater than 0.05 . Table 3 below shows that this is not the case. Assignment is very unlikely to have been fully random.

157 See supra subsection IV.A.2. 
Table 3: Proportion of Three-Month Periods in Which Cross-Judge Differences Were Not Statistically Significant $(p>.05)$

\begin{tabular}{|c|c|c|c|c|}
\hline Court & Mexican & $\begin{array}{c}\text { Entry } \\
\text { Without } \\
\text { Inspection }\end{array}$ & $\begin{array}{c}\text { Central } \\
\text { American }\end{array}$ & Chinese \\
\hline Arlington & $19 \%$ & $44 \%$ & $26 \%$ & $96 \%$ \\
\hline Atlanta & 70 & 63 & 74 & 85 \\
\hline Baltimore & 74 & $5^{2}$ & 33 & 96 \\
\hline Boston & 59 & 41 & 41 & 78 \\
\hline Buffalo & 81 & 89 & 100 & 100 \\
\hline Chicago & 30 & 37 & 63 & 85 \\
\hline Dallas & 59 & 63 & 78 & 93 \\
\hline Detroit & $5^{2}$ & 59 & 78 & 85 \\
\hline Harlingen & 48 & 89 & 52 & 96 \\
\hline Houston & 44 & 63 & 33 & 89 \\
\hline Los Angeles & 0 & 0 & 22 & 15 \\
\hline Miami & 41 & 0 & 7 & 78 \\
\hline New York City & 44 & 30 & 41 & 15 \\
\hline Newark & 67 & 44 & 67 & 78 \\
\hline Orlando & 56 & 56 & 81 & 89 \\
\hline Philadelphia & 33 & 41 & $5^{2}$ & 74 \\
\hline San Antonio & 44 & 41 & 30 & 96 \\
\hline San Diego & 67 & 67 & 96 & 100 \\
\hline San Francisco & 4 & 15 & 44 & 74 \\
\hline
\end{tabular}

Because assignment does not appear to be random, I went on to test, first, whether controlling for observable differences significantly alters my estimates of relief rates. Second, I tested whether the results hold for a subsample of courts and time periods in which assignment may have been random.

To control for observable differences, I estimated a regression with year and court fixed effects and judge random effects.158 In order to satisfy the assumptions of the random effects model, judge effects should be approximately normally distributed. To check whether this assumption is plausible, I plot the actual distribution of judge relief rates below and overlay a normal distribution with the same standard deviation.

158 In choosing a random effects model to measure cross-judge disparities, I follow Yang, supra note 1. 
Figure 8: Distribution of Relief Rates

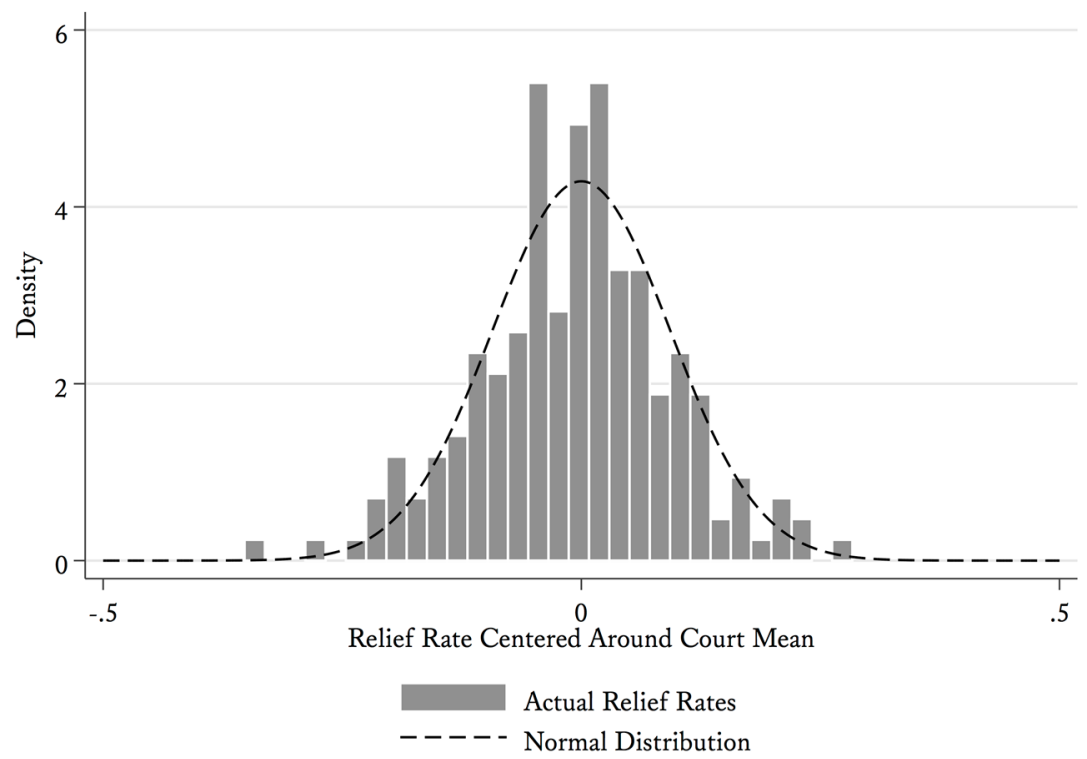

I therefore fit a model of the form

$$
\begin{gathered}
Y_{i j c t}=X_{i j c t} \beta+\gamma_{c}+\delta_{t}+\gamma_{c} * \delta t+v_{i j c t} \\
\text { where } v_{i j c t}=\mu_{j c t}+\varepsilon_{i j c t}
\end{gathered}
$$

$Y_{i j c t}$ is binary outcome159 for immigration case $i$ before immigration judge $j$ in immigration court $c$ in year $t$, and $X_{i j c t}$ is a vector of control variables. 160 Immigration court fixed effects $\left(\gamma_{c}\right)$ and year fixed effects $\left(\delta_{t}\right)$ are included. $\mu_{j c t}$ is the judge mean, estimated in a random effects specification, and $\varepsilon_{i j c t}$ is an individual-level error term. The standard deviation of interest is the standard deviation of $\mu_{j c t}$.

I used this model to assess whether nonrandom assignment is substantively important, checking whether controlling for these deviations significantly

159 This variable is $\mathrm{o}$ if a case ends with deportation and 1 if it does not. I code cases as not leading to deportation if the recorded outcome was any of the following: "Alien Maintains Legal Status"; "Case Terminated by IJ"; "Conditional Grant"; "Granted"; "Relief or Rescinded"; or "Legally Admitted." I code cases as leading to deportation if the outcome was any of: "Remove"; "Voluntary Departure"; "Excluded"; or "Deported."

160 These are (1) the number of charges per immigrant, (2) an indicator for whether the immigrant is Mexican, (3) an indicator for whether the immigrant is Central American, (4) an indicator for whether the immigrant is charged with a crime-related ground for removal, and (5) whether the immigrant is charged with entry without inspection. 
changes estimates of judges' relief rates. Figure 8 compares simple centered relief rates to rates estimated from a random effects regression with controls. The two distributions look relatively similar, and the simple rates actually vary slightly less than the rates with controls-the opposite of what one would expect if the assignment process were causing the cross-judge disparities.

Figure 9: Judge Relief Rates With vs. Without Nationality and Charge Controls

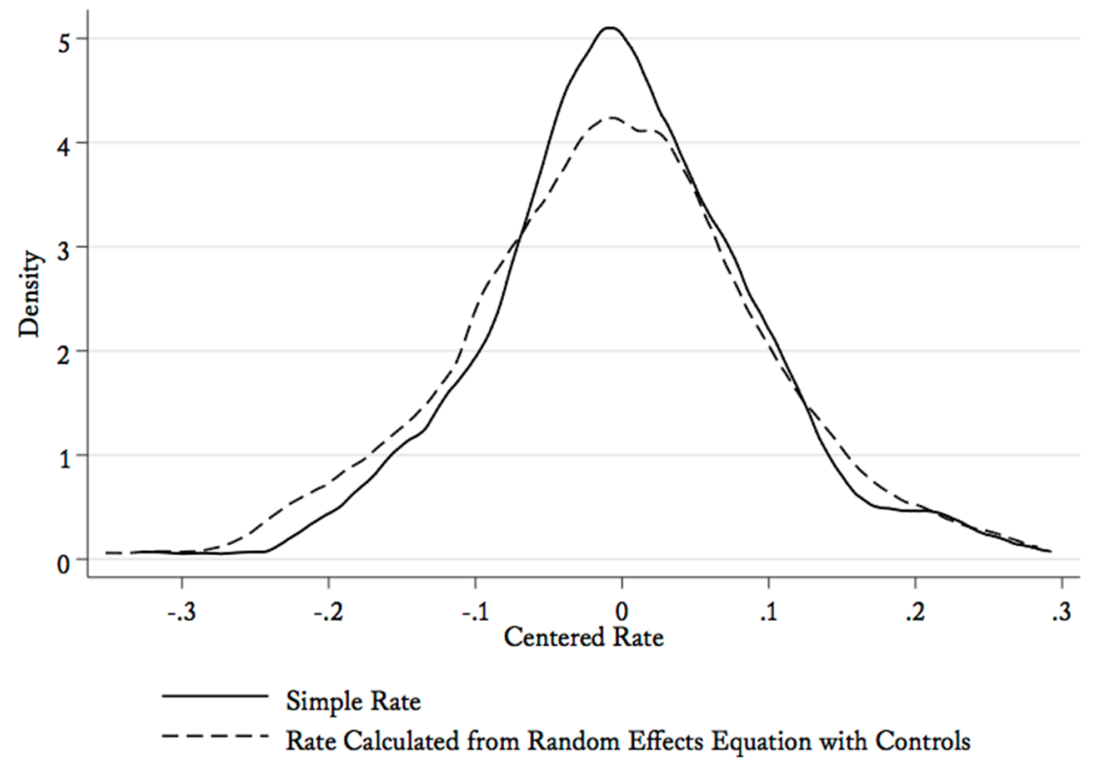

Of course, the similarity of the densities might be deceptive-individual judge relief rates might be affected by the control variables, even if the spread remains similar. I therefore checked the correlation between the random effects coefficients and the simple means. It is 0.97 , suggesting that controlling for observable differences has only a small effect.

\section{B. Subsample}

In order to identify time periods and courts in which assignment of cases to judges was likely to be random, I began with the full EOIR data set of nondetained cases, rather than only the cases initiated between 1998 and 2004. I then narrowed the data set to courts that had heard at least 8000 cases in order to work only with courts that might yield large enough samples within each period. Next, I divided the data into three month periods, and 
for each three month period in each court, I performed Chi-squared tests for independence across judges for each of the four variables mentioned earlier: (1) proportion Mexican immigrants; (2) proportion Central American immigrants; (3) proportion of immigrants facing crime-related immigration charges; and (4) proportion of immigrants facing the charge of entry without inspection. After conducting these tests, I narrowed the sample to courts and time periods in which the $p$-value from none of the four Chi-squared tests was below 0.1. I then eliminated courts and time periods in which there were fewer than two judges who decided at least fifty cases. This yielded a set of 123,454 cases from twenty-nine courts initiated between 1997 and 2013. Notably, these criteria excluded two of the four largest courts-Los Angeles and Miami-from the analysis entirely.

I then estimated the same random effects model as in the analysis above with court-period fixed effects and judge random effects.

Table 4: Subsample Judge Standard Deviations

\begin{tabular}{lcc}
\hline \hline & & $95 \%$ Confidence \\
Dependent Variable & SD Point Estimate & Interval \\
\hline Deportation & $6.4 \%$ & $6.1-7.9 \%$ \\
Representation & 4.7 & $4.3-5.6$ \\
Relief Application & 5.2 & $4.7-6.1$ \\
\hline
\end{tabular}

The effects are significantly smaller than those reported for the full analysis, but they are also for a different set of courts. I therefore compared estimates for six courts for which there are many observations from both samples.161 The results from the subsample and full sample are relatively similar, with a few exceptions. The differences in Atlanta stand out especially. This may reflect the different sample periods - in Atlanta, half of the cases in the subsample were initiated after 2005 and so were excluded from the full sample.

161 These are the six courts with the most observations from the subsample in which random assignment is plausible and which are also in the larger nineteen-court sample. 
Table 5: Subsample and Full Sample Point Estimates

\begin{tabular}{lcccccc}
\hline \hline & \multicolumn{2}{c}{ Deportation } & \multicolumn{2}{c}{ Representation } & \multicolumn{2}{c}{ Relief Application } \\
\cline { 2 - 7 } & & Full & & Full & & Full \\
& Subsample & Sample & Subsample & Sample & Subsample & Sample \\
\cline { 2 - 7 } Atlanta & $0 \%$ & $10.1 \%$ & $3.1 \%$ & $14.3 \%$ & $5.0 \%$ & $12.7 \%$ \\
Baltimore & 7.2 & 8.1 & 5.2 & 2.9 & 9.6 & 9.3 \\
Boston & 9.9 & 11.4 & 0 & 0 & 2.7 & 2.6 \\
Buffalo & 2.1 & 2.1 & 7.6 & 4.7 & 8.5 & 3.0 \\
Harlingen & 11.5 & 6.0 & 1.1 & 0.5 & 1.3 & 1.7 \\
Newark & 4.7 & 3.6 & 6.3 & 2.6 & 3.2 & 3.3 \\
\hline
\end{tabular}

Overall, the substantive similarity of the results suggests that the observational approach adopted in the bulk of this Article returned estimates that are not systematically biased. However, the differences do encourage caution in interpreting the point estimates. The claims that I make do not depend, however, on a precise interpretation of these estimates.

\section{Appeals Regressions}

To assess the effect of judge relief rates on appeal filings and success, I used the following linear probability model:

$$
Y_{i j c t}=\beta_{0}+\beta_{1} X_{i c t}+\beta_{2} J_{c t}+\beta_{3} R_{i c t}+\beta_{4}\left(R_{i j c t} * J_{c t}\right)+\Gamma_{c t}+e_{i c t}
$$

where $J$ is the immigration judge's unweighted relief rate for $c$ immigration courts and $t$ years, $R$ is an indicator variable for whether an immigrant $i$ is represented, $X$ is a vector of control variables, 162 and $\Gamma$ represents fixed effects for courts and years.163 Standard errors are clustered on the immigration judge. I estimate this model separately for appeals initiated by immigrants and by the government, for two dependent variables: whether an appeal was filed; and whether, given a filed appeal, the appellant won remand or reversal.164 For each model, I interpret the effect of the judge relief rate as causal because, as I have argued, judge relief rates are arbitrarily assigned.165 I do not, however, interpret the effect of representation as causal: the difference

162 These include the number of charges, along with indicators for whether a charge is related to crime or entry without inspection, as well as indicators for whether an immigrant is Mexican or from a Central American country. Most importantly, I also controlled for each judge's average number of days elapsed before immigrants find lawyers.

163 The year is measured as of the date of the Notice to Appear.

164 See infra Tables 6-11.

165 See supra note 45 and accompanying text. 
in appeal rates could reflect differences in the merits of the cases or in the sophistication of the immigrants rather than the effect of a lawyer.

I use nearly identical regression models to measure the effect of generosity on petition for review to courts of appeals, but I condition these results on losing before the BIA. The results should be treated with caution: because the petition for review data only occasionally provide a filing date, there is no reliable way to match petitions for review to BIA decisions. For example, if an immigrant appeals to the BIA, has her appeal denied, but then wins on petition for review in a court of appeals and has the case remanded to the immigration judge but loses again, appeals again to the BIA, and then wins before the BIA, that case is excluded, since I included only cases in which the most recent BIA decision was a deportation decision. Despite these concerns, the substantive results largely match those at the BIA level.

Below are ten regression tables. The first six (Tables 6-11) summarize patterns in appeals filings and outcomes when immigrants appeal and when the government appeals. The next two (Tables 12-13) display patterns in filing and outcomes on petition for review, and the final two (Tables 14-15) show the effects of streamlining on patterns in appeals to the BIA and petitions for review. 
Table 6: Dependent Variable: Immigrant Files Appeal (if Ordered Removed)

\begin{tabular}{|c|c|c|c|c|}
\hline & (1) & (2) & (3) & (4) \\
\hline Demeaned Judge & $-0.23^{* *}$ & $-0.23^{* *}$ & -0.050 & $-0.21^{* *}$ \\
\hline Relief Rate & $(0.075)$ & $(0.070)$ & $(0.061)$ & $(0.072)$ \\
\hline \multicolumn{2}{|l|}{ Number of Charges on } & $-0.014^{*}$ & $-0.024^{* * *}$ & $-0.014^{*}$ \\
\hline \multicolumn{2}{|l|}{ Notice to Appear } & $(0.0070)$ & $(0.0043)$ & $(0.0070)$ \\
\hline \multicolumn{5}{|l|}{ (NTA) } \\
\hline \multirow[t]{2}{*}{ Crime-Related Charge } & & -0.015 & -0.033 & -0.014 \\
\hline & & $(0.019)$ & (0.017) & $(0.019)$ \\
\hline \multicolumn{2}{|l|}{ Entered Without } & $0.076^{* * *}$ & -0.0012 & $0.075^{* * *}$ \\
\hline \multicolumn{2}{|l|}{ Inspection } & $(0.0085)$ & $(0.0059)$ & $(0.0085)$ \\
\hline \multirow[t]{2}{*}{ Mexican } & & -0.040 & -0.0099 & -0.039 \\
\hline & & $(0.027)$ & $(0.015)$ & $(0.027)$ \\
\hline \multirow[t]{2}{*}{ Central American } & & $-0.21^{* * *}$ & $-0.080^{* * *}$ & $-0.21^{* * *}$ \\
\hline & & $(0.019)$ & (0.010) & $(0.019)$ \\
\hline \multirow[t]{2}{*}{ Represented } & & & $0.51^{* * *}$ & \\
\hline & & & (0.014) & \\
\hline \multicolumn{3}{|l|}{ Counsel* Judge Relief $^{*}$} & $-0.34^{* *}$ & \\
\hline \multicolumn{2}{|l|}{ Rate } & & $(0.11)$ & \\
\hline \multicolumn{4}{|l|}{ Demeaned Judge } & $0.00012^{*}$ \\
\hline \multicolumn{4}{|l|}{ Average Time } & $(0.000048)$ \\
\hline \multicolumn{5}{|l|}{ Before Lawyer } \\
\hline \multicolumn{5}{|l|}{ Appearance } \\
\hline$N$ & 261,350 & 261,350 & 261,350 & 261,350 \\
\hline \multicolumn{5}{|c|}{ Standard errors in parentheses } \\
\hline \multicolumn{5}{|c|}{ Models include year and court fixed effects } \\
\hline \multicolumn{5}{|c|}{ Standard errors clustered on immigration judge } \\
\hline \multicolumn{5}{|c|}{${ }^{*} p<0.05, "{ }^{* *} p<0.01,{ }^{* * *} p<0.001$} \\
\hline
\end{tabular}


Table 7: Dependent Variable: ICE Files Appeal (if Immigrant Avoids Deportation)

\begin{tabular}{|c|c|c|c|c|}
\hline & (1) & (2) & (3) & (4) \\
\hline Demeaned Judge & $0.079^{* * *}$ & $0.080^{* * *}$ & $0.15^{*}$ & $0.079^{* * *}$ \\
\hline Relief Rate & $(0.016)$ & $(0.016)$ & $(0.062)$ & $(0.015)$ \\
\hline Number of Charges & & $-0.0099^{* * *}$ & $-0.0096 *$ & $-0.0100^{* * *}$ \\
\hline on NTA & & $(0.0028)$ & $(0.0027)$ & $(0.0028)$ \\
\hline Crime-Related & & 0.0013 & -0.0012 & 0.0013 \\
\hline Charge & & $(0.0030)$ & $(0.0031)$ & $(0.0030)$ \\
\hline Entered Without & & $-0.0083^{*}$ & $-0.0098^{* *}$ & $-0.0082^{*}$ \\
\hline Inspection & & $(0.0033)$ & $(0.0034)$ & $(0.0033)$ \\
\hline \multirow[t]{2}{*}{ Mexican } & & $0.015^{* *}$ & $0.015^{* *}$ & $0.015^{* *}$ \\
\hline & & $(0.0047)$ & $(0.0047)$ & $(0.0046)$ \\
\hline \multirow[t]{2}{*}{ Central American } & & $-0.0211^{* * *}$ & $-0.018^{* \cdots *}$ & $-0.021^{* * *}$ \\
\hline & & $(0.0043)$ & $(0.0041)$ & $(0.0042)$ \\
\hline \multirow[t]{2}{*}{ Represented } & & & $0.023^{* \cdots *}$ & \\
\hline & & & $(0.0025)$ & \\
\hline \multicolumn{2}{|l|}{ Counsel* Judge Relief } & & -0.089 & \\
\hline Rate & & & $(0.064)$ & \\
\hline \multicolumn{2}{|l|}{ Demeaned Judge } & & & -0.000036 \\
\hline \multicolumn{2}{|l|}{ Average Time } & & & $(0.000026)$ \\
\hline \multicolumn{5}{|l|}{ Before Lawyer } \\
\hline \multicolumn{5}{|l|}{ Appearance } \\
\hline$N$ & 145,803 & 145,803 & 145,803 & 145,803 \\
\hline \multicolumn{5}{|c|}{ Standard errors in parentheses } \\
\hline \multicolumn{5}{|c|}{ Models include year and court fixed effects } \\
\hline \multicolumn{5}{|c|}{ Standard errors clustered on immigration judge } \\
\hline$" p<0.05, " p<0.0$ & 001 & & & \\
\hline
\end{tabular}


Table 8: Dependent Variable: Alien Wins Appeal (if Filed)

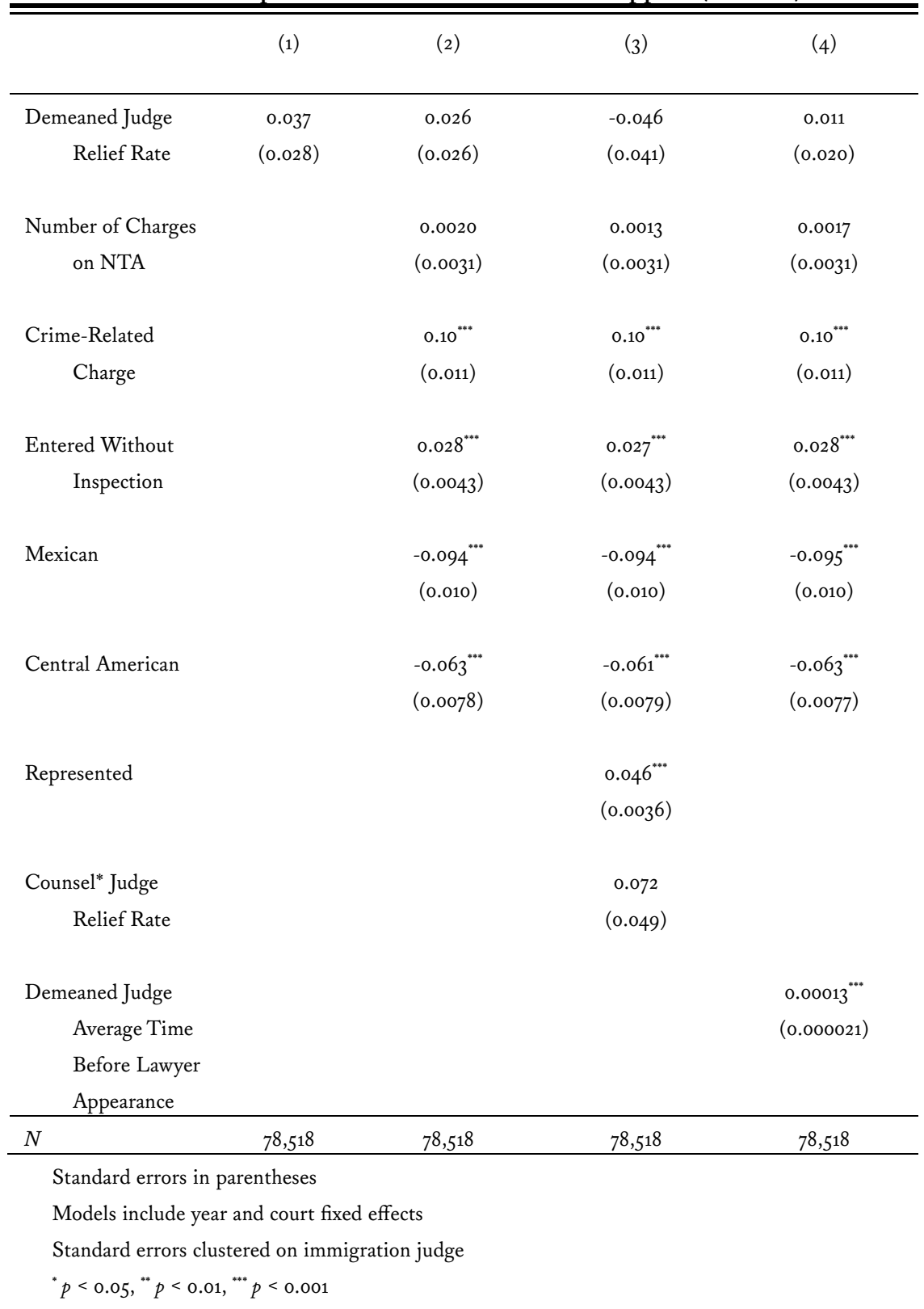


Table 9: Dependent Variable: ICE Wins Appeal (if Filed)

\begin{tabular}{|c|c|c|c|c|}
\hline & (1) & (2) & (3) & (4) \\
\hline Demeaned Judge & 0.21 & 0.18 & 0.14 & 0.19 \\
\hline Relief Rate & $(0.13)$ & $(0.13)$ & $(0.25)$ & $(0.11)$ \\
\hline Number of Charges & & 0.012 & 0.011 & 0.0097 \\
\hline on NTA & & $(0.019)$ & $(0.019)$ & $(0.018)$ \\
\hline Crime-Related & & 0.028 & 0.026 & 0.021 \\
\hline Charge & & $(0.038)$ & $(0.038)$ & $(0.039)$ \\
\hline Entered Without & & 0.045 & 0.044 & 0.040 \\
\hline Inspection & & $(0.030)$ & $(0.030)$ & $(0.030)$ \\
\hline \multirow[t]{2}{*}{ Mexican } & & $0.069^{\circ}$ & $0.066^{*}$ & 0.055 \\
\hline & & $(0.031)$ & $(0.031)$ & $(0.030)$ \\
\hline \multirow[t]{2}{*}{ Central American } & & 0.075 & $0.10^{*}$ & $0.085^{\circ}$ \\
\hline & & $(0.042)$ & $(0.048)$ & $(0.043)$ \\
\hline \multirow[t]{2}{*}{ Represented } & & & $0.13^{* * *}$ & \\
\hline & & & $(0.037)$ & \\
\hline Counsel* Judge & & & 0.066 & \\
\hline Relief Rate & & & $(0.30)$ & \\
\hline Demeaned Judge & & & & $0.00064^{* * *}$ \\
\hline Average Time & & & & $(0.00012)$ \\
\hline \multicolumn{5}{|l|}{ Before Lawyer } \\
\hline \multicolumn{5}{|l|}{ Appearance } \\
\hline$N$ & 4736 & 4736 & 4736 & 4736 \\
\hline \multicolumn{5}{|c|}{ Standard errors in parentheses } \\
\hline \multicolumn{5}{|c|}{ Models include year and court fixed effects } \\
\hline \multicolumn{5}{|c|}{ Standard errors clustered on immigration judge } \\
\hline$" p<0.05,{ }^{* *} p<0$ & 0.001 & & & \\
\hline
\end{tabular}


Table 10: Dependent Variable $=1$ if Alien Files and Wins Appeal

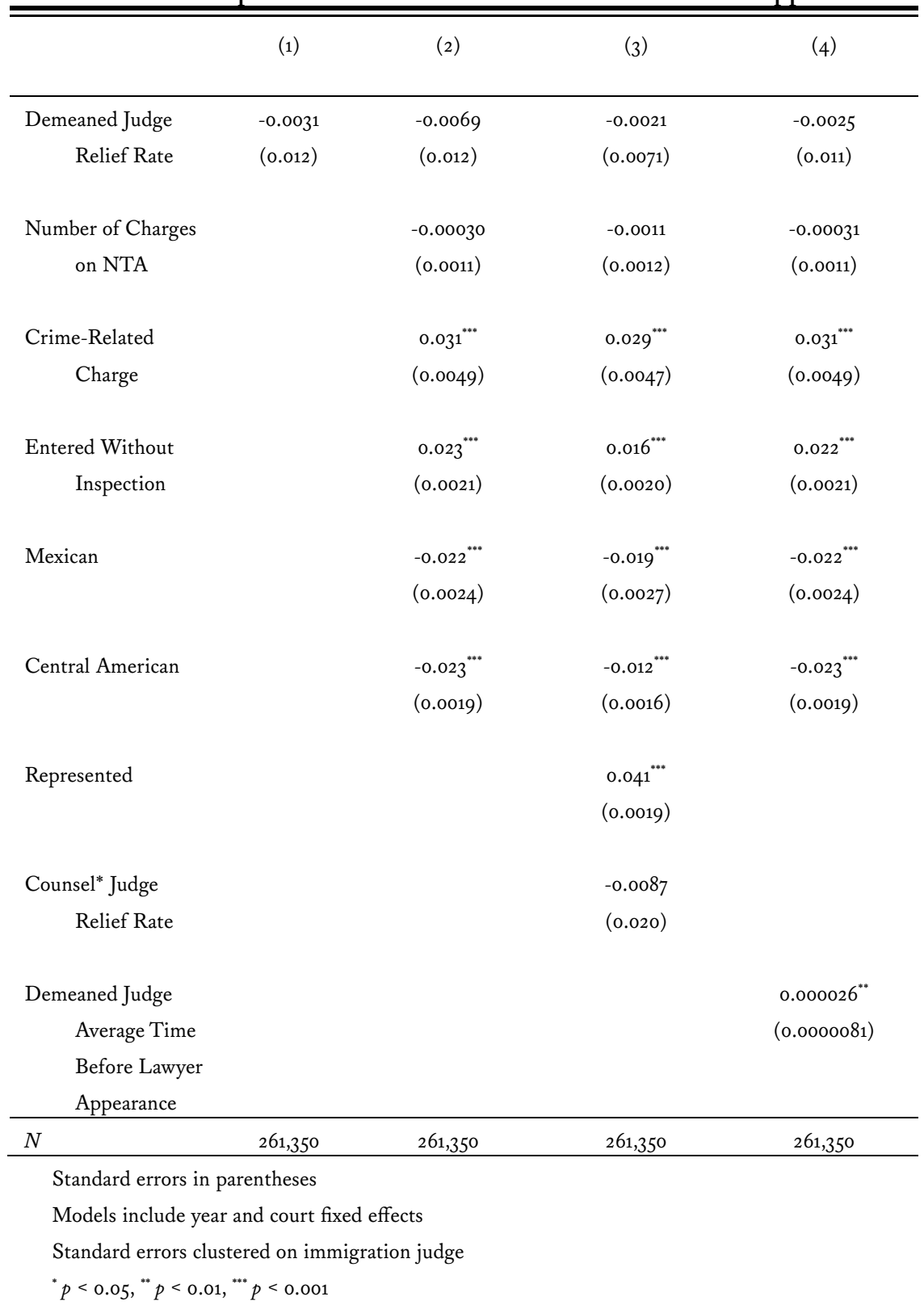


Table 11: Dependent Variable $=1$ if ICE Files and Wins Appeal

\begin{tabular}{|c|c|c|c|c|}
\hline & (1) & (2) & (3) & (4) \\
\hline Demeaned Judge & $0.042^{* * *}$ & $0.043^{* * *}$ & 0.080 & $0.042^{* * *}$ \\
\hline Relief Rate & $(0.0099)$ & $(0.0099)$ & $(0.043)$ & $(0.0096)$ \\
\hline Number of Charges & & 0.0012 & 0.0013 & 0.0012 \\
\hline on NTA & & $(0.00078)$ & $(0.00078)$ & $(0.00078)$ \\
\hline Crime-Related & & 0.0029 & 0.0019 & 0.0029 \\
\hline Charge & & $(0.0016)$ & $(0.0017)$ & $(0.0016)$ \\
\hline Entered Without & & $0.0033^{* *}$ & $0.0026^{\circ}$ & $0.0033^{*}$ \\
\hline Inspection & & (0.0011) & $(0.0011)$ & $(0.0011)$ \\
\hline \multirow[t]{2}{*}{ Mexican } & & $0.013^{\cdots \cdots}$ & $0.013^{* * *}$ & $0.013^{* * *}$ \\
\hline & & $(0.0027)$ & $(0.0027)$ & $(0.0027)$ \\
\hline \multirow[t]{2}{*}{ Central American } & & 0.00030 & 0.0013 & 0.00030 \\
\hline & & $(0.0017)$ & $(0.0015)$ & $(0.0017)$ \\
\hline \multirow[t]{2}{*}{ Represented } & & & $0.0096^{* * *}$ & \\
\hline & & & $(0.0012)$ & \\
\hline Counsel* Judge & & & -0.047 & \\
\hline Relief Rate & & & $(0.043)$ & \\
\hline Demeaned Judge & & & & -0.0000053 \\
\hline Average Time & & & & $(0.000019)$ \\
\hline \multicolumn{5}{|l|}{ Before Lawyer } \\
\hline \multicolumn{5}{|l|}{ Appearance } \\
\hline$N$ & 145,803 & 145,803 & 145,803 & 145,803 \\
\hline \multicolumn{5}{|c|}{ Standard errors in parentheses } \\
\hline \multicolumn{5}{|c|}{ Models include year and court fixed effects } \\
\hline \multicolumn{5}{|c|}{ Standard errors clustered on immigration judge } \\
\hline${ }^{*} p<0.05, "{ }^{*} p<0$. & $p<0.001$ & & & \\
\hline
\end{tabular}


Table 12: Dependent Variable: Immigrant Files Petition for Review

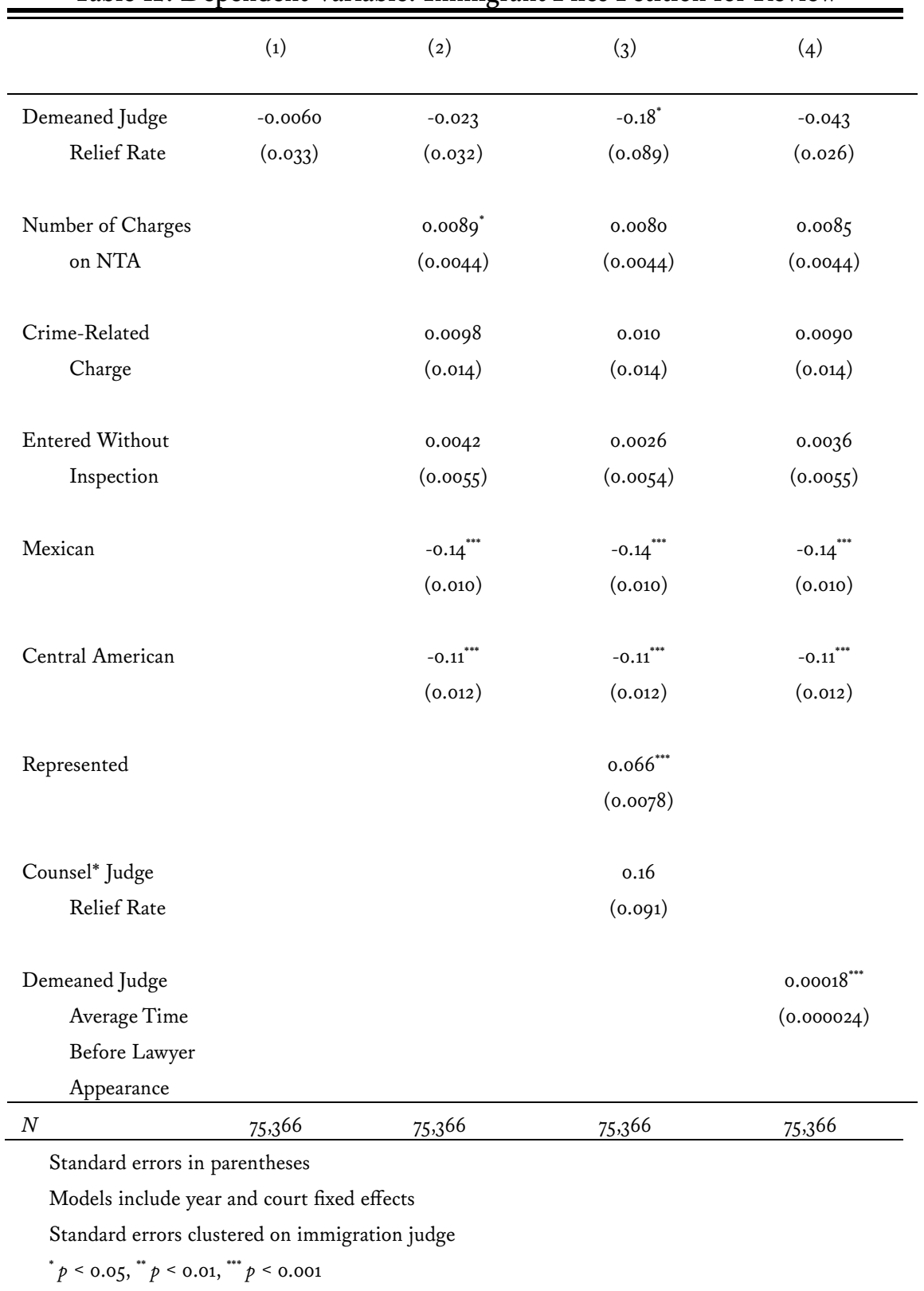


Table 13: Dependent Variable: Immigrant Wins Remand on Petition for Review

\begin{tabular}{|c|c|c|c|c|}
\hline & (1) & (2) & (3) & (4) \\
\hline Demeaned Judge & -0.026 & -0.036 & 0.021 & -0.042 \\
\hline Relief Rate & $(0.073)$ & $(0.072)$ & $(0.080)$ & $(0.066)$ \\
\hline Number of Charges & & 0.00084 & 0.00060 & 0.00071 \\
\hline on NTA & & $(0.0046)$ & $(0.0046)$ & $(0.0046)$ \\
\hline Crime-Related & & 0.018 & 0.018 & 0.018 \\
\hline Charge & & $(0.012)$ & $(0.012)$ & $(0.012)$ \\
\hline Entered Without & & 0.010 & 0.010 & 0.0099 \\
\hline Inspection & & $(0.0068)$ & $(0.0068)$ & $(0.0068)$ \\
\hline \multirow[t]{2}{*}{ Mexican } & & $-0.049^{\cdots * *}$ & $-0.049^{* * *}$ & $-0.049^{* * *}$ \\
\hline & & $(0.0095)$ & $(0.0095)$ & $(0.0093)$ \\
\hline \multirow[t]{2}{*}{ Central American } & & $-0.039^{\cdots \cdots}$ & $-0.038^{* * *}$ & $-0.040^{* * *}$ \\
\hline & & $(0.011)$ & $(0.011)$ & $(0.011)$ \\
\hline \multirow[t]{2}{*}{ Represented } & & & $0.034^{* * *}$ & \\
\hline & & & $(0.0079)$ & \\
\hline Counsel* Judge & & & -0.059 & \\
\hline Relief Rate & & & $(0.091)$ & \\
\hline Demeaned Judge & & & & $0.000093^{\circ}$ \\
\hline Average Time & & & & $(0.000038)$ \\
\hline \multicolumn{5}{|l|}{ Before Lawyer } \\
\hline \multicolumn{5}{|l|}{ Appearance } \\
\hline$N$ & 20,572 & 20,572 & 20,572 & 20,572 \\
\hline \multicolumn{5}{|c|}{ Standard errors in parentheses } \\
\hline \multicolumn{5}{|c|}{ Models include year and court fixed effects } \\
\hline \multicolumn{5}{|c|}{ Standard errors clustered on immigration judge } \\
\hline${ }^{*} p<0.05, " * p<$ & .0 & & & \\
\hline
\end{tabular}


Table 14: Effects of Streamlining on Appeals to the BIA

\begin{tabular}{|c|c|c|c|c|}
\hline & $\begin{array}{c}(1) \\
\text { Immigrant } \\
\text { Files } \\
\end{array}$ & $\begin{array}{l}(2) \\
\text { Government } \\
\text { Files } \\
\end{array}$ & $\begin{array}{c}(3) \\
\text { Immigrant } \\
\text { Files \& Wins } \\
\end{array}$ & $\begin{array}{c}\quad(4) \\
\text { Government } \\
\text { Files \& Wins } \\
\end{array}$ \\
\hline $\begin{array}{c}\text { Demeaned Judge } \\
\text { Relief Rate }\end{array}$ & $\begin{array}{l}-0.17^{* * *} \\
(0.039)\end{array}$ & $\begin{array}{l}0.040^{* * *} \\
(0.0090)\end{array}$ & $\begin{array}{l}-0.016^{*} \\
(0.0054)\end{array}$ & $\begin{array}{l}0.0046^{*} \\
(0.0019)\end{array}$ \\
\hline $\begin{array}{l}\text { Demeaned Judge Average } \\
\text { Time Before Lawyer } \\
\text { Appearance }\end{array}$ & $\begin{array}{l}-0.000029 \\
(0.000022)\end{array}$ & $\begin{array}{l}-0.000034^{* *} \\
(0.000010)\end{array}$ & $\begin{array}{c}0.0000043 \\
(0.0000039)\end{array}$ & $\begin{array}{l}-0.0000039 \\
(0.0000042)\end{array}$ \\
\hline $\begin{array}{l}\text { Number of Charges } \\
\text { on NTA }\end{array}$ & $\begin{array}{c}0.011^{*} \\
(0.0047)\end{array}$ & $\begin{array}{l}-0.0053^{* *} \\
(0.0018)\end{array}$ & $\begin{array}{l}-0.0019^{*} \\
(0.00081)\end{array}$ & $\begin{array}{c}0.0011^{*} \\
(0.00046)\end{array}$ \\
\hline Crime-Related Charge & $\begin{array}{l}0.021^{* *} \\
(0.0071)\end{array}$ & $\begin{array}{l}-0.00057 \\
(0.0015)\end{array}$ & $\begin{array}{l}0.0061^{\cdots * *} \\
(0.0017)\end{array}$ & $\begin{array}{c}0.00097 \\
(0.00060)\end{array}$ \\
\hline $\begin{array}{l}\text { Entered Without } \\
\text { Inspection }\end{array}$ & $\begin{array}{l}0.055^{* * *} \\
(0.0050)\end{array}$ & $\begin{array}{l}-0.015^{* * *} \\
(0.0038)\end{array}$ & $\begin{array}{l}0.018^{* * *} \\
(0.0021)\end{array}$ & $\begin{array}{c}0.0010 \\
(0.00085)\end{array}$ \\
\hline Mexican & $\begin{array}{l}-0.10^{\cdots \cdots} \\
(0.0088)\end{array}$ & $\begin{array}{l}0.0019 \\
(0.0019)\end{array}$ & $\begin{array}{l}-0.024^{\cdots *} \\
(0.0018)\end{array}$ & $\begin{array}{l}0.0021^{* * *} \\
(0.00063)\end{array}$ \\
\hline Central American & $\begin{array}{l}-0.10^{\cdots \cdots} \\
(0.0071)\end{array}$ & $\begin{array}{l}-0.011^{* *} \\
(0.0017)\end{array}$ & $\begin{array}{l}-0.025^{* * *} \\
(0.0018)\end{array}$ & $\begin{array}{l}0.000011 \\
(0.00044)\end{array}$ \\
\hline $\begin{array}{l}\text { Indicator for Post- } \\
\text { Streamlining } \\
\text { Decision }\end{array}$ & $\begin{array}{l}0.75^{* * *} \\
(0.0090)\end{array}$ & $\begin{array}{l}0.75^{* * *} \\
(0.015)\end{array}$ & $\begin{array}{l}0.030^{* * *} \\
(0.0025)\end{array}$ & $\begin{array}{l}0.28^{* * *} \\
(0.023)\end{array}$ \\
\hline $\begin{array}{l}\text { Post-Streamlining* Judge } \\
\text { Relief Rate }\end{array}$ & $\begin{array}{l}0.14^{* *} \\
(0.042)\end{array}$ & $\begin{array}{c}0.83^{* * *} \\
(0.15)\end{array}$ & $\begin{array}{l}0.039^{*} \\
(0.020)\end{array}$ & $\begin{array}{l}0.73^{* * *} \\
(0.19)\end{array}$ \\
\hline$N$ & 573,745 & 311,007 & 573,745 & 311,007 \\
\hline $\begin{array}{l}\text { Standard errors in pare } \\
\text { Models include year-cc } \\
\text { Standard errors cluster } \\
\text { Post-Streamlining mea } \\
{ }^{*} p<0.05,{ }^{* *} p<0.01,{ }^{*}\end{array}$ & $\begin{array}{l}\text { eses } \\
\text { fixed effects } \\
\text { on immigrati } \\
\text { mmigration } \\
0.001\end{array}$ & $\begin{array}{l}\text { dge } \\
\text { decisions afte }\end{array}$ & $\operatorname{arch} 1,2002$ & \\
\hline
\end{tabular}


Table 15: Effects of Streamlining on Petitions for Review

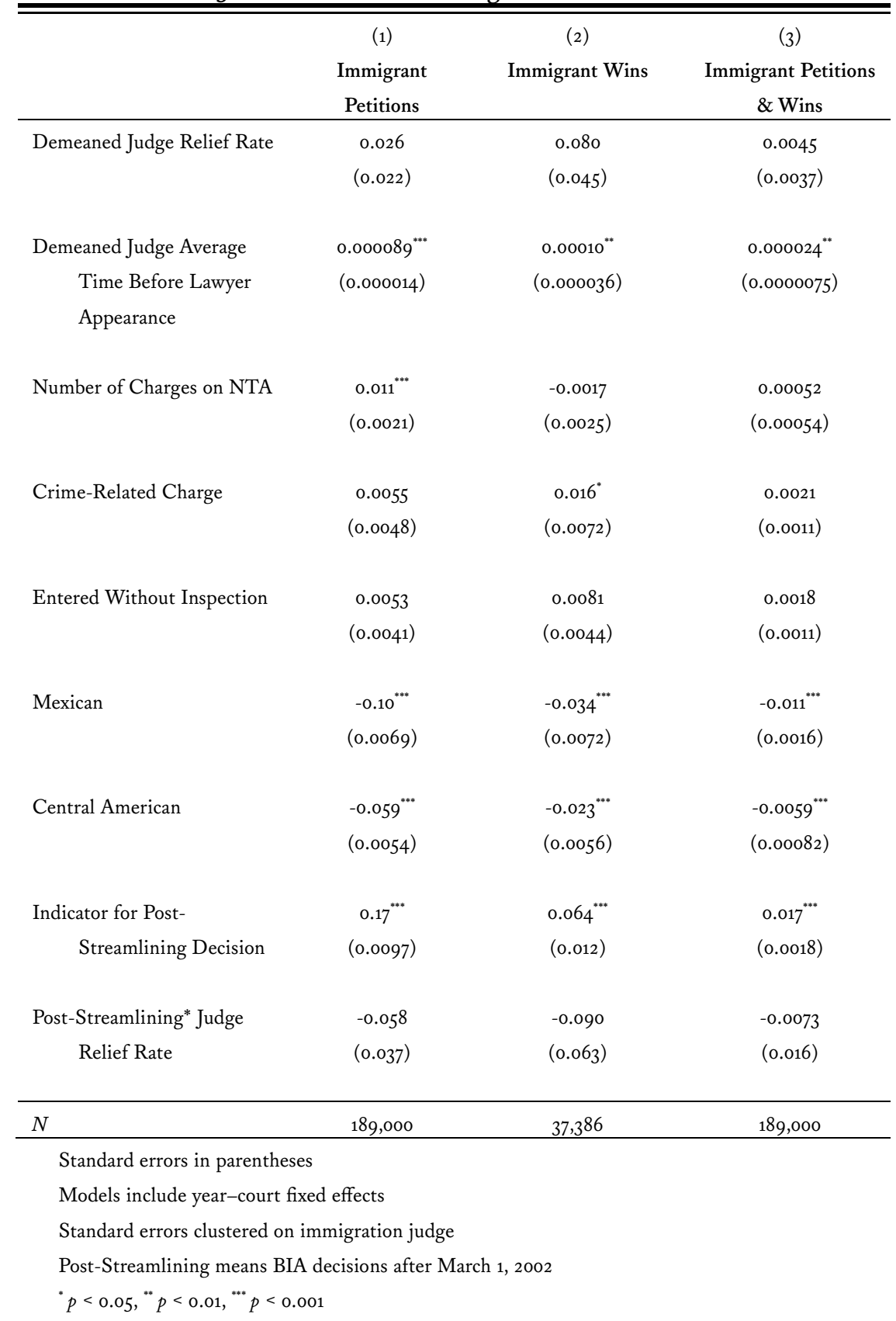

